\title{
C-Terminal 1-Aminoethyltetrazole-Containing Oligopeptides as Novel Alanine Racemase Inhibitors
}

\author{
Laszlo A. Kondacs ${ }^{1}$ (D), Sylvain Orenga ${ }^{2}$, Rosaleen J. Anderson ${ }^{1,+}$, Emma C.L. Marrs ${ }^{3}$, \\ John D. Perry ${ }^{3}$ and Mark Gray ${ }^{1, *}$ \\ 1 Sunderland Pharmacy School, University of Sunderland, Sunderland SR1 3SD, UK; \\ laszlo.kondacs@kcl.ac.uk (L.A.K.); roz.anderson@sunderland.ac.uk (R.J.A.) \\ 2 Research \& Development Microbiology, bioMérieux, 38390 La Balme-les-Grottes, France; \\ sylvain.orenga@biomerieux.com \\ 3 Department of Microbiology, Freeman Hospital, Newcastle upon Tyne NE7 7DN, UK; \\ e.marrs@nhs.net (E.C.L.M.); john.perry@nuth.nhs.uk (J.D.P.) \\ * Correspondence: mark.gray@sunderland.ac.uk \\ $\dagger$ Deceased.
}

Academic Editors: Paul Groundwater, David E. Hibbs and Linda Varadi Received: 15 February 2020; Accepted: 9 March 2020; Published: 13 March 2020

\begin{abstract}
In clinical culture media inoculated with patient samples, selective inhibition of commensal bacteria is essential for accurate diagnosis and effective treatment, as they can mask the presence of pathogenic bacteria. The alanine analogue, 1-aminoethyltetrazole was investigated as a potential alanine racemase inhibitor. For effective uptake and enhanced and selective antibacterial activity, a library of C-terminal 1-aminoethyltetrazole containing di- and oligopeptides were synthesized by solid phase peptide coupling techniques. The investigation of the antimicrobial activity of the synthesised compounds identified several clinically applicable selective inhibitors. These enabled differentiation between the closely related bacteria, Salmonella and Escherichia coli, which can be difficult to discriminate between in a clinical setting. In addition, differentiation between enterococci and other Gram-positive cocci was also seen.
\end{abstract}

Keywords: alanine racemase; 1-aminoethyltetrazole; antibacterial agent; selective inhibition; solid phase peptide synthesis

\section{Introduction}

In order to treat bacterial infections effectively, and to avoid promoting the evolution of bacterial resistance against antibacterial drugs, the correct agents must be used. Therefore, rapid and accurate detection and identification of pathogenic strains are essential. Chromogenic and fluorogenic culture media are used routinely in the clinical environment for this purpose [1]. A limitation of such media occurs due to the presence of additional non-pathogenic bacteria which are commonly found in clinical samples, the presence of which could produce false signals. One way to overcome this problem is to add selective antibacterial agents to the medium that can specifically prevent the growth of irrelevant strains, but allow the pathogen under investigation to grow [2].

Our target was the widely-studied enzyme [3] alanine racemase (AlaR). This enzyme plays a key role in the biosynthesis of bacterial peptidoglycan through its activity in the racemisation of L-alanine to D-alanine in bacteria. In the past, several alanine racemase inhibitors have been reported $[3,4]$, and some have been applied as antimicrobial agents. Examples of these include L,L-alafosfalin (1), the more active prodrug form of the direct AlaR inhibitor L-fosfalin (2). Figure 1 shows these known alanine racemase inhibitors, which are structurally similar to the natural substrate.

While L-fosfalin (2) is a good AlaR inhibitor in isolated enzyme studies [5], it does not produce significant antimicrobial effects when applied to intact bacteria. This is thought to be because it passes 
through the cell membrane in insufficient quantities to harm the bacteria. In turn, this is due to the highly ionised and polar character of this molecule, precluding passive diffusion. The more effective compound alafosfalin (1) contains two parts, the AlaR inhibitor fosfalin and a carrier alanine moiety. Despite also being highly polar, this molecule effectively inhibits the growth of many intact bacterial strains. This is because, unlike fosfalin itself, it is able to conscript the dipeptide permease system to cross the bacterial membrane and, after hydrolysis by an intracellular alanine aminopeptidase, it liberates fosfalin (2) as the active agent [6].<smiles>C[C@H](N)C(=O)N[C@@H](C)P(=O)(O)O</smiles>

1<smiles>C[C@H](N)P(=O)(O)O</smiles>

2

Figure 1. Examples of the known alanine racemase inhibitors, alafosfalin (1) and fosfalin (2).

The cost of producing enantiomerically pure L-fosfalin is high and the antibacterial selectivity of its derivatives is limited [7]. Due to these factors, there is scope for the development of a new series of AlaR inhibitors. The tetrazole moiety has been utilised as a bioisostere for carboxylic acids in drugs such as Losartan, where problems occurred with membrane permeability earlier in the development cycle [8]. Thus, to see if a tetrazole bioisoteric replacement would produce interesting activity against AlaR in intact bacteria, L-1-aminoethyltetrazole 4a-L was prepared and studied as an alanine (3) bioisostere (Figure 2). In addition, oligopeptide derivatives containing a C-terminal L-1-aminoethyltetrazole were synthesised from this initial material.<smiles>CC(N)C(=O)O</smiles>

3<smiles>CC(N)c1nnn[nH]1</smiles>

Figure 2. Alanine (3) and a tetrazole containing bioisostere $4 \mathbf{a}-\mathbf{L}$, designed as the basis for a series of potential AlaR inhibitors.

\section{Results and Discussion}

\subsection{Chemistry}

The synthesis of the key molecule L-1-aminoethyltetrazole 4a-L has been published by Bavetsias [9]. This synthetic route was followed with minor modifications, producing $\mathbf{4 a - L}$ in good overall yield (71\%) (Scheme 1).

Cbz-L-Alanine 5a-L was methylated with methyl iodide in the presence of $\mathrm{Cs}_{2} \mathrm{CO}_{3}$ in DMF. The resulting methyl ester $\mathbf{6 a} \mathbf{a}-\mathbf{L}$ was transformed to the analogous amide $7 \mathbf{a}-\mathbf{L}$ in the presence of 7 $\mathrm{M}$ ammonia in methanol by heating at $50{ }^{\circ} \mathrm{C}$ in a sealed tube. In the following step, the amide $7 \mathrm{a}-\mathrm{L}$ was converted to nitrile 8a-L using tosyl chloride in pyridine and DCM. Cbz-L-1-aminoethyltetrazole 9a-L was produced by a cycloaddition of the nitrile moiety with $\mathrm{NaN}_{3}$ in the presence of $\mathrm{NH}_{4} \mathrm{Cl}$ in DMF. L-1-Aminoethyltetrazole 4a-L was obtained after removing the Cbz-protecting group by Pd-catalysed hydrogenation. The D-1-aminoethyltetrazole $4 \mathrm{a}-\mathrm{D}$ and L-1-aminopropyltetrazole $4 \mathrm{~b}-\mathrm{L}$ were synthesized by the same methodology. L-1-Aminopropyltetrazole $5 \mathbf{b}-\mathbf{L}$ is a homologue that enabled a preliminary exploration of the steric requirements for tetrazole based inhibitors of AlaR. The justification for this is that (1-amino-2-propenyl)phosphonic acid is an inhibitor of AlaR, [10] which is the comparable homologue of the AlaR inhibitor fosfalin 2.

A series of di- and oligopeptides containing C-terminal L-1-aminoethyltetrazoles were prepared by a solid phase synthetic approach. The tetrazole moiety has been successfully attached to and removed 
from different resins by several research groups [11-14], although to the best of our knowledge its application in peptide chemistry has never been reported. After careful consideration, 2-chlorotrityl chloride resin and the matching Fmoc approach were employed due to the mild cleavage conditions associated with this resin.<smiles>[R]CC(NC(=O)OCc1ccccc1)C(=O)O</smiles>

5-L

R: a-L: H

a-D: $H$

b: $\mathrm{Me}$<smiles>[R]CC(N)c1nnn[nH]1</smiles><smiles>C#CC</smiles>

4-L

yield: a-L: $97 \%$; a-D: $74 \%$; b: $88 \%$<smiles>[R]CC(NC(=O)OCc1ccccc1)C(=O)OCC</smiles>

6-L

yield: a-L: 99\%; a-D: 92\%;

b: $97 \%$<smiles>[R]CC(NC(=O)OCc1ccccc1)c1nnn[nH]1</smiles>

9-L

yield: a-L: $80 \%$; a-D: $81 \%$;

b: $81 \%$<smiles>[R]CC(NC(=O)OCc1ccccc1)C(N)=O</smiles>

7-L

yield: a-L: 99\%; a-D: 75\%

b: $91 \%$

C<smiles>[R]CC(C#N)NC(=O)OCc1ccccc1</smiles>

8-L

yield: a-L: $94 \%$; a-D: $97 \%$; b: $99 \%$

Scheme 1. Synthesis of 1-amino-alkyltetrazoles. Reagents and conditions: (a) $\mathrm{Cs}_{2} \mathrm{CO}_{3}, \mathrm{MeI}, \mathrm{DMF}$; (b) $\mathrm{NH}_{3}(\mathrm{MeOH}), 50{ }^{\circ} \mathrm{C}$; (c) TosCl, pyridine, $\mathrm{DCM}$; (d) $\mathrm{NaN}_{3}, \mathrm{NH}_{4} \mathrm{Cl}, \mathrm{DMF}, 90^{\circ} \mathrm{C}$; (e) $\mathrm{H}_{2}(\mathrm{~g}), 5 \% \mathrm{Pd} / \mathrm{C}$, $\mathrm{EtOH}, 3$ bar [9].

Fmoc-L-1-aminoethyltetrazole 10a-L was prepared by protecting L-1-aminoethyltetrazole $4 \mathbf{a}-\mathrm{L}$ with Fmoc chloride in the presence of $\mathrm{Na}_{2} \mathrm{CO}_{3}$ [15], and then attached to the 2-chlorotrityl chloride resin (Scheme 2) [16]. In our optimised method, the resin was not loaded with an excess amount of the C-terminal unit, which in our case was Fmoc-1-aminoethyltetrazole 10, as is commonly encountered in general practice. The synthetic procedure with fully loaded resin resulted in the isolation of Fmoc peptides as minor impurities at the end, resulting in the requirement for further purification steps. Instead, when loading with a theoretically equivalent ratio, reasonable yields were obtained after cleavage of the peptides (50-70\%) free from the Fmoc peptide impurities that were encountered with a fully saturated resin, Table 1 . The resin bound D-isomer $4 \mathbf{a}-\mathrm{D}$ and L-1-aminopropyltetrazole $4 \mathbf{b}$-L were prepared by the same method.<smiles>[R]CC(N)c1nnn[nH]1</smiles>

R: a-L: H

a-D: $H$ b-L: Me<smiles>[R]CC(NOC(F)F)c1nnn[nH]1</smiles>

10

Yield: a-L: $81 \%$, a-D: 56\%, b-L: $75 \%$

Scheme 2. Synthesis of Fmoc-L-1-aminoalkyltetrazole 10-L and its subsequent attachment to the 2-chlorotrityl chloride resin. Reagents and conditions: (a) Fmoc- $\mathrm{Cl}, \mathrm{Na}_{2} \mathrm{CO}_{3}$ (aq), dioxane; (b) 2-chloro-trityl chloride resin (TP-Cl), DIPEA, DCM.

A series of dipeptide derivatives of 1-aminoalkyltetrazole $\mathbf{1 4 a , b , d - j}$ were synthesized using the same solid phase synthesis approach. First, the Fmoc protection of resin-attached Fmoc-L-1-aminoalkyltetrazole 11a,b was removed with $25 \%$ piperidine solution in DMF. The free amino 
group was coupled with the appropriate $\mathrm{Cbz}$ protected amino acid using HBTU and DIPEA in DMF. The resin-bound dipeptides $\mathbf{1 2} \mathbf{a}, \mathbf{b}, \mathbf{d}-\mathbf{j}$ were cleaved from the resin by a TFA/DCM/triisopropylsilane (TIS) mixture in the ratio 5:95:1 eq (equivalent with the theoretical loading of the resin) and resulted in the protected dipeptides $\mathbf{1 3} \mathbf{a}, \mathbf{b}, \mathbf{d}-\mathbf{j}$ in good to excellent yields (Table 1). The Cbz-protecting group was removed by Pd-catalysed hydrogenation, Scheme 3; the yield of these reactions depended on the purity of the protected starting compound.

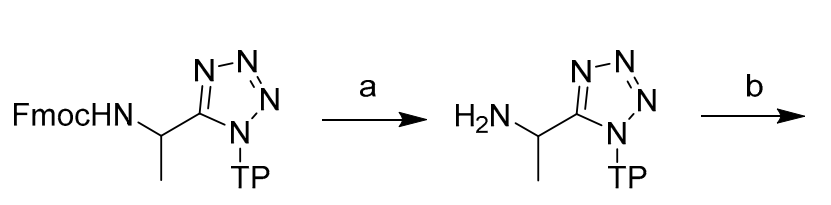

$11 \mathrm{a}$

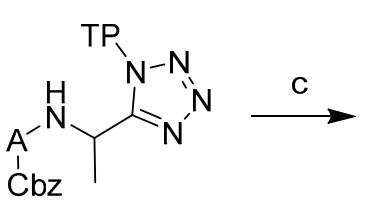

$12 a, d-j$<smiles>CC(C)NC(C)c1nnn[nH]1</smiles>

13a,d - j
A:<smiles>CC(C)NCC1=CCCC1</smiles>

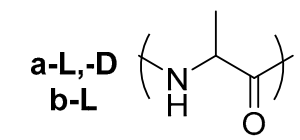<smiles>CC(C)C(=O)CCNC(C)(C)Cl</smiles><smiles>CCCC(NC(C)(Cl)Cl)C1CCC1=O</smiles><smiles>CCCC(=O)C(CC(C)C)NC(C)C</smiles><smiles>C[C@H]1CCCCC1C(=O)C1CC1</smiles><smiles></smiles>

f-L<smiles>O=C(C1CC1)C1CCC(=O)N1C1CC1</smiles>

$$
0
$$<smiles>CNC(C)c1nnn[nH]1</smiles>

$14 a, d-j$<smiles>CC[C@H](N)c1nnnn1[In](C)CC</smiles>

11b-L<smiles>CC[C@H](NC(=O)C(C)C)c1nnn[nH]1</smiles><smiles>CC[C@H](NC(=O)C(C)NC(=O)OCc1ccccc1)c1nnnn1P(F)F</smiles>

$12 b$<smiles>CC[C@H](NC(=O)C(C)NC(=O)OCc1ccccc1)c1nnn[nH]1</smiles>

Scheme 3. Solid phase synthesis of dipeptide derivatives of L-1-aminoethyltetrazole $\mathbf{1 4 a}, \mathbf{b}, \mathbf{d}-\mathbf{j}$. Reagents and conditions: (a) piperidine, DMF; (b) Cbz-A-OH, HBTU, DIPEA, DMF; (c) 5\% TFA, 95\% DCM, 1 eq TIS (equivalent with the theoretical loading of the resin); (d) $\mathrm{H}_{2}, 0.5 \% \mathrm{Pd} / \mathrm{C}, \mathrm{MeOH}, 3$ bar. 
Table 1. Yields and conditions for Scheme 3: Abbreviations: p: the cleaved mixture was triturated and washed with petroleum ether $40-60^{\circ} \mathrm{C}$ before yield and impurity calculation; n.o.: not observed; a: the loading was possibly inhomogeneous, and might have been washed with an insufficient amount of piperidine in DMF.

\begin{tabular}{|c|c|c|c|c|c|}
\hline & Abbreviation & $\begin{array}{c}\text { Loading Ratio (Fmoc- } \\
\text { 1-aminoethyltetrazole } \\
\text { 10: resin) }\end{array}$ & $\begin{array}{l}\text { Theoretical } \\
\text { Yield of } 13 \\
\quad(\%) \text { p }\end{array}$ & $\begin{array}{l}\text { Percentage of } \\
\text { Fmoc Residue } \\
\text { in } 13 \%\end{array}$ & Yield of $14(\%)$ \\
\hline $14 \mathrm{~g}-\mathrm{L}$ & Gly-L-Ala(T) & $1: 1$ & 59 & n.o. & 99 \\
\hline 14a-LL & L-Ala-L-Ala(T) & $1: 1$ & 58 & 5 & 86 \\
\hline 14a-LD & L-Ala-D-Ala(T) & $1: 1$ & 89 & $<1$ & 58 \\
\hline 14d-LL & $\beta$-Ala-L-Ala(T) & $1: 1$ & 67 & 2 & 78 \\
\hline 14e-LL & L-Nor-L-Ala(T) & $1: 1$ & 51 & $14 a$ & 77 \\
\hline 14h-LL & L-Leu-L-Ala(T) & $2: 1$ & 84 & 6 & 81 \\
\hline 14h-LD & L-Leu-D-Ala(T) & $1: 1$ & 69 & $<1$ & 53 \\
\hline 14i-LL & L-Ile-L-Ala(T) & $1: 1$ & 62 & 2 & 86 \\
\hline 14f-LL & L-Pyr-L-Ala(T) & $2: 1$ & 89 & 12 & 84 \\
\hline $14 \mathrm{j}$-LL & L-Phe-L-Ala(T) & $1: 1$ & 79 & $15 a$ & 20 \\
\hline 14b-LL & L-Ala-L-EtGly(T) & $1: 1$ & 52 & 3 & 86 \\
\hline
\end{tabular}

A tripeptide analogue, L-alanyl-L-alanyl-L-1-aminoethyltetrazole 14-c-LLL was accessed by coupling the attached L-1-aminoethyltetrazole 15-L with an Fmoc-L-alanine, and then with a Cbz-L-alanine. Cbz-L-alanyl-L-alanyl-L-1-aminoethyltetrazole 13c-LLL was cleaved from the resin with a mixture of 5\% TFA, 95\% DCM, 1 eq TIS. Subsequent Cbz deprotection by catalytic hydrogenation resulted in L-alanyl-L-alanyl-L-1-aminoethyltetrazole 14c-LLL (Scheme 4).
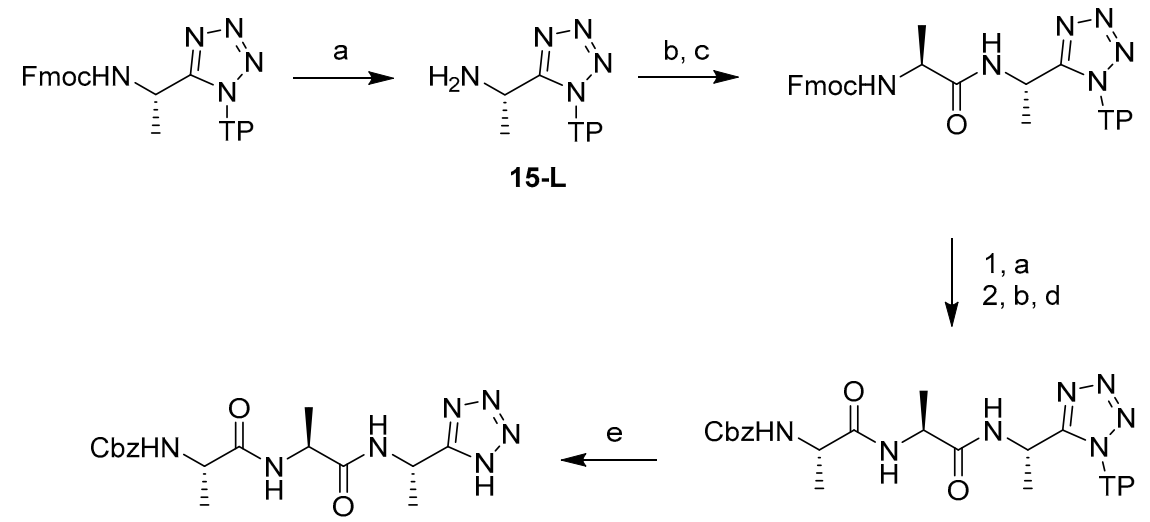

13c-LLL

Yield: $47 \% *$

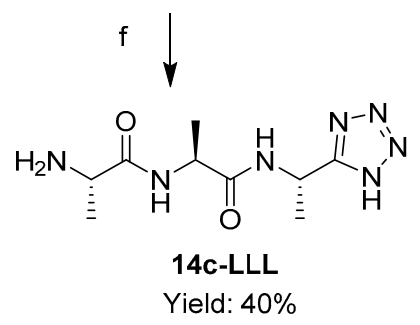

Scheme 4. Solid phase synthesis of L-alanyl-L-alanyl-L-1-aminoethyltetrazole 14c-LLL. Reagents and conditions: (a) piperidine, DMF; (b) HBTU, DIPEA, DMF; (c) Fmoc-L-Alanine; (d) Cbz-L-Alanine; (e) 5\% TFA, 95\% DCM, 1 eq TIS; (f) $\mathrm{H}_{2}, 0.5 \% \mathrm{Pd} / \mathrm{C}, \mathrm{MeOH}, 3$ bar. 
A series of di-, tri- and tetra-peptidyl derivatives of N-terminal succinyl-, C-terminal L-1-aminoethyltetrazole 16-LL, 17-LLL, 18-LLLL were synthesised by the same strategy. After the introduction of the appropriate number of alanine residues (1-3), the peptides were furnished with a succinyl group using succinic anhydride and DIPEA in DMF. These substrates were intended to target bacterial elastase enzymes in order to achieve a different pattern of selective inhibition. The rationale behind this lay in the knowledge that succinyl-tripeptides were cleaved from chromogenic peptidase substrates by Pseudomonas aeruginosa in a previous study [17].

AlthougH-N-Cbz protected peptides were successfully cleaved from the resin by a mixture of $5 \%$ TFA, 95\% DCM, 1 eq TIS, with good solubility in the cleavage medium, the succinyl peptides 16-LL, 17-LLL, 18-LLLL were not sufficiently soluble in this organic solvent mixture. Due to this they were instead cleaved from the resin by a better solubilising mixture of $95 \%$ TFA, $2.5 \% \mathrm{H} 2 \mathrm{O}, 2.5 \%$ TIS. This method was both effective and convenient, due to the lack of a need for a N-terminal protecting group, Scheme 5 .
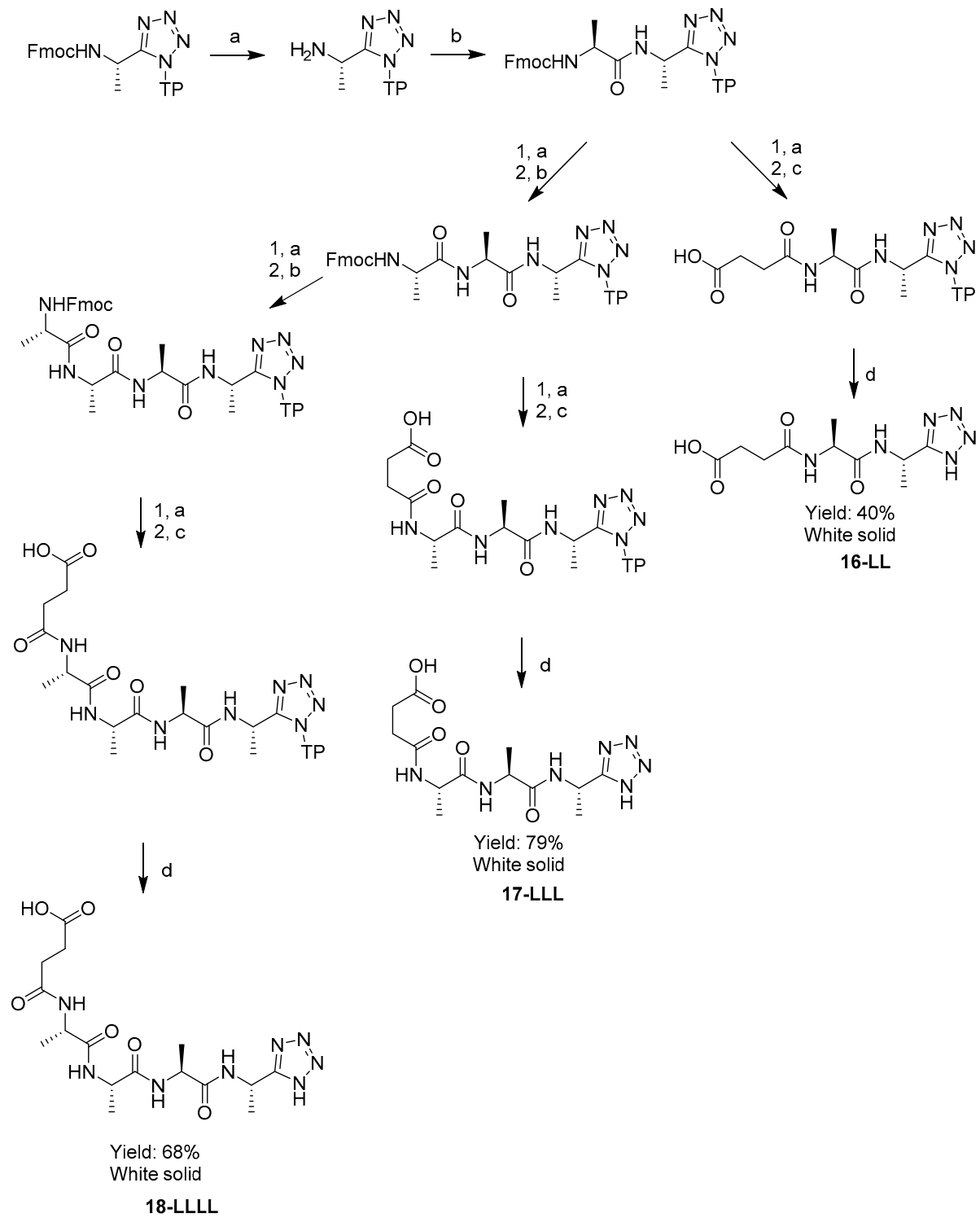

17-LLL

Scheme 5. Solid phase synthesis of series of N-terminal succinyl-, C-terminal L-1-aminoethyltetrazole oligopeptides 21-LL, 22-LLL, 23-LLLL. Reagents and conditions: (a) piperidine, DMF; (b) Fmoc-LAlanine, HBTU, DIPEA, DMF; (c) Succinic anhydride, DIPEA, DMF; (d) 95\% TFA, 2.5\% $\mathrm{H}_{2} \mathrm{O}, 2.5 \%$ TIS. 


\subsection{Microbiological Evaluation}

All of the synthesised 1-aminoethyltetrazole derivatives were tested against a panel of clinically relevant pathogenic bacteria to investigate their antibacterial properties. The minimum inhibitory concentration (MIC) tests were carried out in antagonist-free, blood supplemented agar media containing the appropriate 1-aminoethyltetrazole compound in different concentrations (1-128 mg/L). L-Alanyl-L-alanyl-L-1-aminoethyltetrazole 14c-LLL and L-alanyl-L-1-aminoethyltetrazole 14a-LL have been synthesized and tested against a selected group of bacteria in the past: Escherichia coli, Staphylococcus aureus and Salmonella enterica serovar Dublin. In this previous work they were reported to be inactive, which contrasts starkly with the data we report below. However, these differences in results may be attributed to differences in the culture medium that was used, such as peptone content, the specific bacterial strains studied or even differences in the inoculum $[18,19]$. Our more extensive investigation focused upon clinically relevant strains of pathogenic bacteria, and used protocols that have now been established as clinical standard over many years.

L-1-Aminoethyltetrazole 4a-L and the D-enantiomer 4a-D displayed no activity when tested at concentrations of up to $128 \mathrm{mg} / \mathrm{L}$ against our panel of clinically relevant bacteria. As already stated, the natural amino acid alanine is transported as oligopeptide forms into bacterial cells, and not as a single amino acid [20]. This latest result suggests that the increase in lipophilicity associated with changing the carboxylate in the natural compound to the tetrazole in our analogue does not produce effective passive diffusion at an extent that would lead to significant antimicrobial activity. Furthermore, L-1-aminopropyltetrazole $4 \mathbf{b}$-L was also inactive when exposed to the bacteria as the single amino acid analogue.

In marked contrast to the results with the single amino acid analogues, targeting the dipeptide permease systems of bacteria proved to be successful and is consistent with the intracellular liberation of L-1-aminoethyltetrazole 4a-L (Table 2). Depending upon the N-terminal amino acid, the growth of different Gram-negative and Gram-positive bacteria can be inhibited, thus selectivity can be tuned by choosing specifiC-Natural N-terminal amino acids within the oligopeptide analogues.

Importantly, it was shown that L,L-alanyl peptide 14a-LL was effective in inhibiting the growth of many Gram-negative species, but did not display inhibition against Salmonella. This pattern of activity leads to an obvious and important application for this compound; it could be used in Salmonella selective media to improve the clinical detection of Salmonella from stool samples, in which overgrowth by commensal gut bacteria, such as E. coli, is problematic [1].

The glycyl peptide 14g-L was only active against a few species, and even then, only in higher concentrations. In addition, the $\beta$-alanyl 14d-L substrate did not show any antibacterial activity. This compound was aimed at targeting $\beta$-alanyl aminopeptidase, which only presents in a few bacteria, most notably Pseudomonas aeruginosa [21], Serratia marcescens and Burkholderia cepacia [22]. This result suggests that either the side chain or the chirality of the N-terminal amino acid might have an important role in their transportation. Previously reported corresponding $\beta$-alanyl derivatives of the AlaR inhibitor fosfalin and $\beta$-chloroalanine also had limited activities against bacteria, despite other peptide derivatives of these compounds being well known effective and selective antibacterial agents [23-25].

The compounds displaying longer, more lipophilic side chains i.e., the peptide analogues L,L-norvalyl 14e-LL, leucyl 14h-LL, isoleucyl 14i-LL and phenylalanyl 14j-LL displayed enhanced antibacterial activity against Gram-positive bacteria, and suggest roles as new wide spectrum and selective antibacterial agents. However, what the current data set does not tell us is why this enhancement in activity is seen. 
Table 2. MIC values (mg/L) of C-terminal 1-aminoethyltetrazole containing dipeptides 14a,d-j; NCTC: National Collection of Type Cultures, Colindale, UK; ATCC: American Type Culture Collection, Manassas, United States; NT: not tested; a: inoculum 150000 CFU/spot; b: inoculum 10000 CFU/spot; c: the tested compound was prepared by solution phase peptide coupling; $d$ : the tested compound was prepared by solid phase peptide coupling.

\begin{tabular}{|c|c|c|c|c|c|c|c|c|c|c|c|c|}
\hline & & \multicolumn{11}{|c|}{ MIC (mg/L) } \\
\hline & & $14 a-L^{a c}$ & $14 a-L D$ ad & $14 \mathrm{~d}-\mathrm{L}^{\text {ac }}$ & $14 \mathrm{e}-\mathrm{LL}^{\text {ac }}$ & $14 \mathrm{~h}-\mathrm{LD}^{\text {ad }}$ & $14 \mathrm{i}-\mathrm{LL}^{\text {ad }}$ & $14 \mathrm{f}-\mathrm{LL}^{\text {ac }}$ & $14 \mathrm{~b}-\mathrm{LL}^{\text {ad }}$ & $14 \mathrm{~g}-\mathrm{L}^{\mathrm{bd}}$ & $14 \mathrm{~h}-\mathrm{LL}^{\mathrm{bc}}$ & $14 \mathrm{j}-\mathrm{LL}^{\mathrm{bd}}$ \\
\hline Gram-negative species & Strain code & Ala- & Ala- & $\beta$-Ala- & Nor- & Leu- & Ile- & Pyr- & Ala- & Gly- & Leu- & Phe- \\
\hline Acinetobacter baumannii & ATCC 19606 & $>128$ & $>128$ & $>128$ & $>128$ & $>128$ & $>128$ & $>128$ & $>128$ & $>128$ & $>128$ & $>128$ \\
\hline Burkholderia cepacia & ATCC 25416 & $>128$ & $>128$ & $>128$ & $>128$ & $>128$ & $>128$ & $>128$ & $>128$ & $>128$ & $>128$ & $\leq 1$ \\
\hline Enterobacter cloacae & NCTC 11936 & $\leq 1$ & $>128$ & $>128$ & $\leq 1$ & $>128$ & 4 & $>128$ & 8 & 32 & $\leq 1$ & 8 \\
\hline Escherichia coli & NCTC 10418 & $\leq 1$ & $>128$ & $>128$ & $\leq 1$ & $>128$ & 8 & $>128$ & $>128$ & $>128$ & $\leq 1$ & 4 \\
\hline Klebsiella pneumoniae & NCTC 9528 & $\leq 1$ & $>128$ & $>128$ & $\leq 1$ & $>128$ & $>128$ & 8 & $>128$ & $>128$ & 2 & 16 \\
\hline Providencia rettgeri & NCTC 7475 & $>128$ & $>128$ & 128 & $>128$ & $>128$ & $>128$ & $>128$ & $>128$ & $>128$ & $>128$ & $>128$ \\
\hline Pseudomonas aeruginosa & NCTC 10662 & 64 & $>128$ & $>128$ & 64 & $>128$ & 128 & $>128$ & $>128$ & $>128$ & 64 & $>128$ \\
\hline Salmonella Typhimurium & NCTC 74 & $>128$ & $>128$ & $>128$ & 2 & $>128$ & 128 & $>128$ & $>128$ & $>128$ & 64 & $>128$ \\
\hline Serratia marcescens & NCTC 10211 & 2 & $>128$ & $>128$ & $\leq 1$ & $>128$ & 16 & 8 & $>128$ & $>128$ & $\leq 1$ & 8 \\
\hline Yersinia enterocolitica & NCTC 11176 & $\leq 1$ & $>128$ & $>128$ & $\leq 1$ & $>128$ & 2 & 4 & $>128$ & 128 & $\leq 1$ & NT \\
\hline Escherichia coli & NCTC 12241 & $\leq 1$ & $>128$ & $>128$ & $\leq 1$ & $>128$ & 2 & $>128$ & $>128$ & 64 & $\leq 1$ & 4 \\
\hline Salmonella Enteritidis & NCTC 6676 & $>128$ & $>128$ & $>128$ & $>128$ & $>128$ & $>128$ & $>128$ & $>128$ & $>128$ & $>128$ & $>128$ \\
\hline \multicolumn{13}{|l|}{ Gram-positive species } \\
\hline Enterococcus faecalis & NCTC 775 & $>128$ & $>128$ & $>128$ & $\leq 1$ & $>128$ & $>128$ & 2 & $>128$ & $>128$ & 2 & 2 \\
\hline Enterococcus faecium & NCTC 7171 & $>128$ & $>128$ & $>128$ & 2 & $>128$ & 64 & 2 & $>128$ & $>128$ & 16 & 32 \\
\hline Listeria monocytogenes & NCTC 11994 & $>128$ & $>128$ & $>128$ & 4 & $>128$ & $>128$ & $>128$ & $>128$ & $>128$ & $>128$ & $>128$ \\
\hline Staphylococci epidermidis & NCTC 11047 & $>128$ & $>128$ & $>128$ & 2 & $>128$ & $>128$ & $>128$ & $>128$ & $>128$ & 2 & $>128$ \\
\hline Staphylococcus aureus & NCTC 6571 & $>128$ & $>128$ & 64 & 4 & 128 & 128 & $>128$ & $>128$ & 64 & 16 & $\leq 1$ \\
\hline $\begin{array}{c}\text { Staphylococcus aureus } \\
\text { (MRSA) }\end{array}$ & NCTC 11939 & $>128$ & $>128$ & 128 & $>128$ & $>128$ & $>128$ & $>128$ & $>128$ & $>128$ & 8 & $>128$ \\
\hline
\end{tabular}


One possibility is that activity against Gram-positive bacteria may occur due to the further lipophilicity associated with the side chains of this group of substrates. This increased lipophilicity could promote passive diffusion as well as, or instead of, active transport into bacteria. Alternatively, the enhanced activity of the peptides displaying longer side chains is consistent with the reported increased affinity for large lipophilic side chains with bacterial proton-dependent oligopeptide transporter proteins [26]. As L,L-leucyl 14h-LL, isoleucyl 14i-LL and phenylalanyl 14j-LL peptides selectively allow the growth of Salmonella species in low concentrations, they also have potential use in a new improved Salmonella selective medium. Another useful finding present within the data is the selective inhibition of enterococci by L-pyroglutamyl derivative 14f-LL [27]. This pyroglutamyl derivative was selected and synthesized to target enterococci, as they are known to produce an active pyroglutamyl aminopeptidase enzyme [28]. The great selectivity displayed by this compound could be attributed to the amide motif on the $\mathrm{N}$-terminus, as the $\mathrm{N}$-terminal amino group is necessary for the transport carried out by permease systems [20]. Interestingly, the D-1-aminoethyltetrazole containing peptides 14a-LD, 14h-LD were totally inactive, although their L-1-aminoethyltetrazole containing diastereomers 14a-LL, 14h-LL inhibited many different species (Table 3). This again suggests an active transport mode of entry wherein the transporter would potentially display chiral selectivity.

Table 3. MIC values of C-terminal 1-aminoethyltetrazole containing oligopeptides; NT: not tested; a: inoculum $150000 \mathrm{CFU} /$ spot; b: inoculum $10000 \mathrm{CFU} /$ spot.

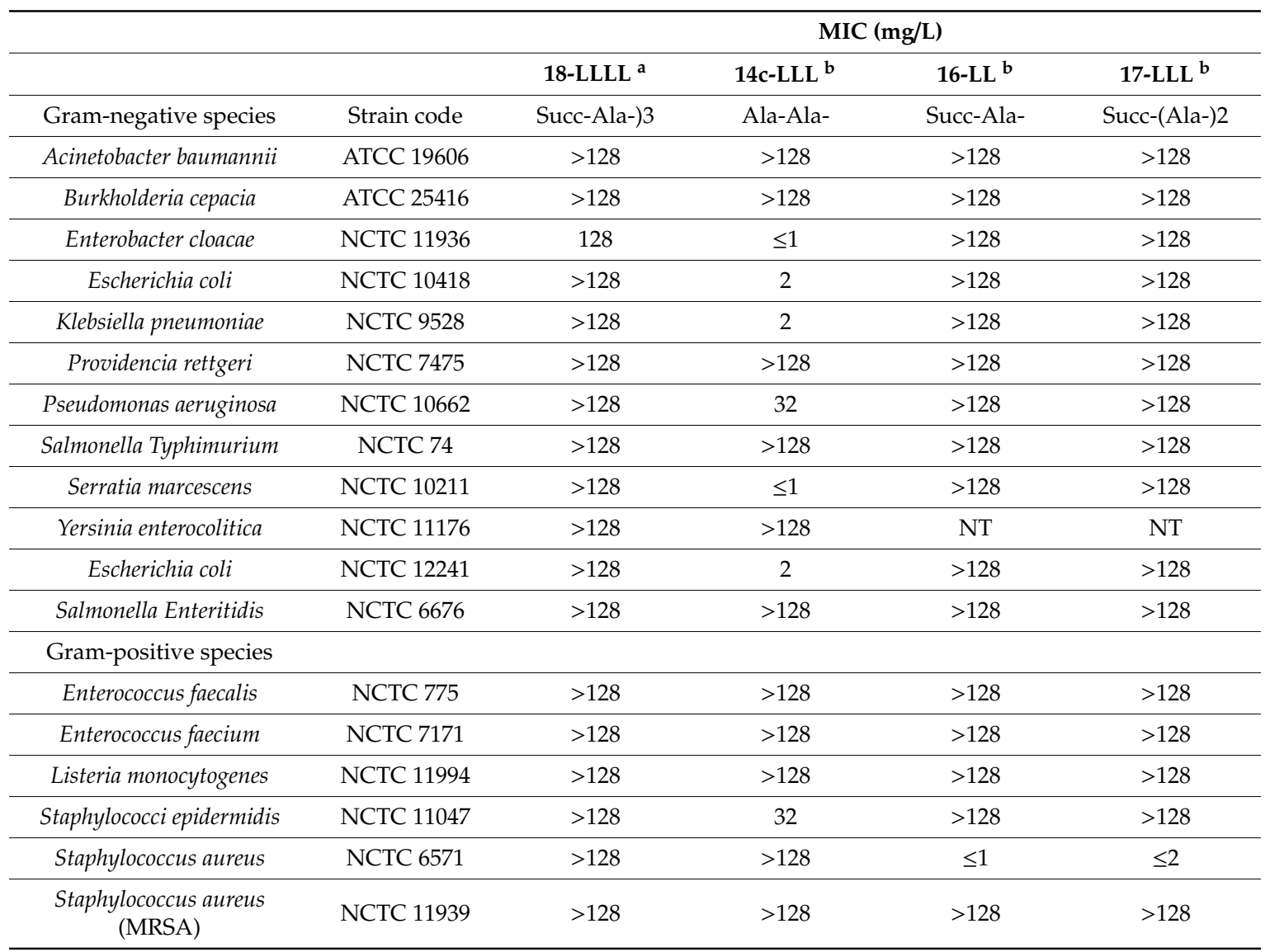

L-Alanyl-L-1-aminopropyltetrazole 14b-LL was found to only inhibit Enterobacter cloacae, among the panel of bacteria that were tested. The contrast between the results obtained with L-alanyl-L-1-aminopropyltetrazole 14b-LL and L-alanyl-L-1-aminoethyltetrazole 14a-LL represents the difference between L-1-aminoethyltetrazole 4a-L and L-1-aminopropyltetrazole 4b-L homologues, as L-1-aminoethyltetrazole 4a-L displays a bioisosteric replacement of the natural substrate of AlaR and can inhibit the enzyme in different species. The larger homologue $4 \mathbf{b}-\mathrm{L}$ probably has 
limited access to the active site of the enzyme in most bacterial AlaRThe tripeptide analogue L-Alanyl-L-alanyl-L-1-aminoethyltetrazole 14c-LLL displayed a similar profile to the previously discussed dipeptides 14a-LL and 14h-LL, which also suggests potential in media where Salmonella detection is required. The N-terminal succinyl containing peptides 16-LL, 17-LLL and 18-LLLL did not produce significant inhibitory effects against most bacteria, Table 3.

\section{Materials and Methods}

\subsection{General Information}

All commercially available reagents and solvents were obtained from Sigma-Aldrich Dorset, UK), Apollo Scientific (Stockport, UK), Alfa Aesar (Heysham, UK), Fluorochem (Glossop, UK), or Fischer Scientific (Loughborough, UK) and were used without further purification. Melting points were recorded on a Reichart-Kofler hot-stage microscope apparatus (Reichart, Vienna, Austria) and are uncorrected. Infrared spectra were recorded in the range $4000-600 \mathrm{~cm}^{-1}$ using a Spectrum BX FT-IR spectrophotometer (Perkin Elmer, Beaconsfield, UK). NMR spectra were obtained using an Ultrashield 300 spectrometer (Bruker, Coventry, UK) at $300 \mathrm{MHz}$ for ${ }^{1} \mathrm{H}$ spectra or at $75 \mathrm{MHz}$ for ${ }^{13} \mathrm{C}$ spectra and a Bruker Avance III Ultrashield spectrometer at $500 \mathrm{MHz}$ for ${ }^{1} \mathrm{H}$ spectra or at $125 \mathrm{MHz}$ for ${ }^{13} \mathrm{C}$ spectra. Low-resolution mass spectra were recorded on a Bruker Esquire 3000plus analyser using an electrospray source in either positive or negative ion mode. High resolution accurate mass measurements were collected by the EPSRC-National Mass Spectrometry Facility at Swansea University. Elemental analyses were performed using an CE-440 Elemental Analyzer (Exeter Analytical, Coventry, UK). Thin layer chromatography was performed on silica gel 60F254 (Merck, Hoddesdon, UK). Thin layer chromatography results were analysed by UV lamp $(254 \mathrm{~nm})$, ninhydrin stain (amine, amide content) and/or ceric ammonium molybdate stain (oxidising agent). Fischer silica gel 60 (35-70 micron, Fischer Scientific, Loughborough, UK) was used for column chromatography; the samples were pre-absorbed onto silica 60 (35-70 micron). LC-MS analysis was performed using a 1290 Infinity Series HPLC system (Agilent, Waldbronn, Germany) and an Agilent 6120 Quadrupole LC-MS detector. LC-MS data was analysed by an Agilent ChemStation. Where required, compounds were purified by Agilent 1260 preparative HPLC. Hydrogenation reactions were performed in a Parr 4560 mini benchtop reactor (SciMed, Stockport, UK). Air and moisture sensitive reactions were carried out in oven dried glassware under a nitrogen atmosphere.

\subsection{Chemistry}

\subsubsection{General Method A: Synthesis of Protected Amino Acid Methyl Ester:}

To a solution of $\mathrm{N}$-protected-amino acid $(26.4 \mathrm{mmol})$ in dry DMF $(70 \mathrm{~mL})$ caesium carbonate $(4.72 \mathrm{~g}, 14.5 \mathrm{mmol})$ was added and the mixture was stirred for $30 \mathrm{~min}$ at room temperature. After dropwise addition of methyl iodide $(1.73 \mathrm{~mL}, 27.8 \mathrm{mmol})$, the reaction was stirred overnight. Ethyl acetate $(50 \mathrm{~mL})$ was then added to the mixture and it was washed with water $(3 \times 50 \mathrm{~mL})$, then the combined aqueous phase was extracted with ethyl acetate $(50 \mathrm{~mL})$. The combined organic phase was washed with $10 \% \mathrm{~K}_{2} \mathrm{CO}_{3}$ solution $(2 \times 30 \mathrm{~mL})$, then with brine $(30 \mathrm{~mL})$, dried over $\mathrm{MgSO}_{4}$, and subsequently filtered. The solvent was removed under reduced pressure to give the product as a white solid.

\subsubsection{General Method B: Synthesis of Protected Amino Amides:}

The protected amino acid methyl ester $(420 \mathrm{mmol})$ was dissolved and stirred in $7 \mathrm{M}$ solution of ammonia in methanol $(60 \mathrm{~mL})$ overnight at $50^{\circ} \mathrm{C}$ in a sealed tube. After the reaction was complete, as determined by TLC, the mixture was evaporated to dryness under reduced pressure. 


\subsubsection{General Method C: Synthesis of Protected Amino Nitrile:}

To a solution of the required N-protected-alanineamide $(19.0 \mathrm{mmol})$ in DCM $(9 \mathrm{~mL})$, pyridine $(14 \mathrm{~mL})$ was added. After cooling to $0{ }^{\circ} \mathrm{C}$, tosyl chloride $(4.7 \mathrm{~g}, 24.7 \mathrm{mmol})$ was added to the solution. Stirring was continued for $30 \mathrm{~min}$ at $0^{\circ} \mathrm{C}$ and then overnight at room temperature. After the reaction as complete, as determined by TLC, the system was cooled to $0{ }^{\circ} \mathrm{C}$ and quenched with water $(70 \mathrm{~mL}) \mathrm{nd}$ ethyl acetate $(70 \mathrm{~mL})$. After separation, the aqueous layer was extracted with ethyl acetate $(4 \times 30 \mathrm{~mL})$ and the combined organic phase was washed with $1.2 \mathrm{M} \mathrm{HCl}(3 \times 40 \mathrm{~mL})$, and saturated $\mathrm{NaHCO}_{3}$ $(50 \mathrm{~mL})$, then brine $(50 \mathrm{~mL})$. The whole solution was dried over $\mathrm{MgSO}_{4}$, and evaporated under reduced pressure.

\subsubsection{General Method D: Synthesis of Cbz-1-Aminoalkyltetrazole:}

To a suspension of $\mathrm{NH}_{4} \mathrm{Cl}(2.03 \mathrm{~g}, 38 \mathrm{mmol})$ and $\mathrm{NaN}_{3}(2.62 \mathrm{~g}, 38 \mathrm{mmol})$ in dry DMF $(60 \mathrm{~mL})$ in a two-necked round bottom flask equipped with reflux condenser and drying tube, the required Cbz-amino nitrile $(38 \mathrm{mmol})$ was added. The mixture was stirred and heated to $90^{\circ} \mathrm{C}$ for $1 \mathrm{~h}$. To the cooled mixture, another portion of $\mathrm{NH}_{4} \mathrm{Cl}(1.04 \mathrm{~g}, 19 \mathrm{mmol})$ and $\mathrm{NaN}_{3}(1.31 \mathrm{~g}, 19 \mathrm{mmol})$ were added and the mixture was heated at $90{ }^{\circ} \mathrm{C}$ overnight. When the reaction was complete, as determined by TLC, the mixture was filtered and the residue was washed with ethyl acetate. The filtrate was evaporated under reduced pressure. Water $(180 \mathrm{~mL})$ was added to the residue and it was acidified to $\mathrm{pH} 1$ with $2.5 \mathrm{M} \mathrm{HCl}$ aqueous solution. The precipitated solid was filtered off and washed with water to give the product.

\subsubsection{General Method E: Removal of the Cbz Protecting Group:}

To the solution of the protected amino acid or peptide derivative (1.0 meq) in methanol, $5 \%$ palladium on activated carbon $(0.1 \mathrm{meq})$ was added portion wise. The mixture was stirred at room temperature under 2 bar pressure of hydrogen overnight in an autoclave. After the reaction was complete determined by TLC, the mixture was filtered through celite and then the solvent removed in vacuum.

\subsubsection{General Method F: Fmoc Protection:}

$10 \%$ Aqueous $\mathrm{Na}_{2} \mathrm{CO}_{3}(13 \mathrm{~mL})$ was added to the suspension of 1-aminolakyltetrazole (4.87 mmol) in 1,4-dioxane $(7 \mathrm{~mL})$. After the addition of Fmoc chloride (1.38 g, $5.35 \mathrm{mmol})$ solution in 1,4-dioxane $(7 \mathrm{~mL})$, the mixture was stirred for $30 \mathrm{~min}$ at $0{ }^{\circ} \mathrm{C}$, then overnight at room temperature. When the reaction was complete, as determined by TLC, it was acidified with $2.5 \mathrm{M} \mathrm{HCl}$ aqueous solution $(11 \mathrm{~mL})$. The mixture was filtered and the solid product was washed with water before drying.

\subsubsection{General Method G: Solid Phase Peptide Coupling:}

Swelling: The resin was bubbled for $30 \mathrm{~min}$ in a long-necked glass sinter in a solvent (DMF or DCM) with a volume $3 x$ that of the bed volume. Subsequently the solvent was removed by filtration.

Washing off: The resin was washed with DMF $(3 \times 8 \mathrm{~mL}$ for $30 \mathrm{~s})$, IPA $(2 \times 8 \mathrm{~mL}$ for $30 \mathrm{~s})$ and finally with petroleum ether $\left(40-60^{\circ} \mathrm{C}\right)(2 \times 8 \mathrm{~mL}$ for $30 \mathrm{~s})$. The resin was air-dried, then dried in a vacuum oven at $40{ }^{\circ} \mathrm{C}$ overnight. The solvents were removed by filtration after each step.

Attachment to 2-chlorotrityl chloride resin: After swelling the resin in DCM the solution of Fmoc-1-aminoalkyltetrazole 4 and DIPEA in DCM was added to the resin, and the mixture was bubbled for $2 \mathrm{~h}$. After filtration, the resin was bubbled with DCM, DIPEA and methanol mixture for $1 \mathrm{~h}$. Later the resin was washed with DMF $(3 \times 8 \mathrm{~mL}$ for $30 \mathrm{~s})$, methanol $(3 \times 8 \mathrm{~mL}$ for $30 \mathrm{~s})$ then with DCM or petroleum ether $\left(40-60{ }^{\circ} \mathrm{C}\right)(3 \times 8 \mathrm{~mL}$ for $30 \mathrm{~s})$ depending on whether the resin needed to be swelled or dried. The solvents and solutions were removed by filtration after each step.

Fmoc deprotection: The resin swelled in DMF was treated with a mixture of piperidine and DMF (1:4 ratio, $10 \mathrm{~mL} / \mathrm{g}$ resin, $1 \times 5 \mathrm{~min}$ and $3 \times 10 \mathrm{~min}$ ), then it was alternately washed with DMF and IPA 
$(2 \times 8 \mathrm{~mL}$ for $30 \mathrm{~s})$ finished with washing with DMF $(8 \mathrm{~mL}$ for $30 \mathrm{~s})$. The solvents and solutions were removed by filtration after each step.

Fmoc test: A sample consisting of a few resin beads was washed with DMF $(4 \times 1 \mathrm{~mL}$ for $30 \mathrm{~s})$, IPA $(5 \times 1 \mathrm{~mL}$ for $30 \mathrm{~s})$ and with methanol $(2 \times 1 \mathrm{~mL}$ for $30 \mathrm{~s})$, followed by transfer into a separate flask by washing with $1 \%$ TFA in DCM $(2 \times 1 \mathrm{~mL}$ for $30 \mathrm{~s})$. The filtrate was placed on a TLC plate with a capillary and observed under UV light $(254 \mathrm{~nm})$. A positive test shows fluorescence on the TLC plate. The solvents and solutions were removed by filtration after each step.

Coupling: DIPEA (1 eq) was added to the solution of HBTU ( 3 eq) and the protected amino acid (3 eq) in DMF (10 mL). The solution was stirred for $8 \mathrm{~min}$ and then it was added to the swelled resins. After 20 min bubbling witH-Nitrogen, more DIPEA (0.5 eq) was added to the mixture, then it was bubbled until the TNBS test showed a negative result. After the reaction was complete the resin was washed off using the procedure mentioned above.

Coupling with succinic anhydride: The solution of succinic anhydride (3 eq) in DMF (10 mL) was added to the swelled resins, followed by the addition of DIPEA (1 eq). It was bubbled until the TNBS test showed a negative result (typically $1 \mathrm{~h}$ ). After the reaction was over the resin was washed off using the procedure mentioned above.

TNBS test: The solution of DIPEA in DMF (10\%, 3 drops) and the aqueous solution of TNBS ( $1 \mathrm{M}$, 3 drops) were mixed with sample consisting of a few resin beads. After a waiting period of $10 \mathrm{~min}$, the resin beads were inspected under a light microscope (magnification $4 \times$ ). The result was positive if the beads were coloured red, orange or yellow and it was negative if the beads were colourless.

Cleavage from resin: The resin swelled in DCM was treated with 1\% TIS containing TFA, DMF mixture (5:95 ratio, $10 \mathrm{~mL} / \mathrm{g}$ ) for $1 \mathrm{~h}$. After washing the resin with the same TFA, DCM mixture, the filtrate was evaporated under reduced pressure. (Supplementary Materials).

HPLC method A: column: ACE 5 C18 (150 $\times 3 \mathrm{~mm}$ i.d.); eluent: isocratic: water $(0.1 \%$ formic acid $)$ - methanol ( $0.1 \%$ formic acid) $95: 5$ ratio. The purity of all the compounds tested using this method were $\geq 95 \%$.

HPLC method B: column: ACE 5 C18 $(150 \times 3 \mathrm{~mm}$ i.d.); eluent: isocratic: water $(0.1 \%$ formic acid $)$ - methanol (0.1\% formic acid) 80:20 ratio. The purity of all the compounds tested using this method were $\geq 95 \%$.

HPLC method C: column: ACE 5 C18 $(150 \times 3 \mathrm{~mm}$ i.d.); eluent: isocratic: water $(0.1 \%$ formic acid $)$ - methanol ( $0.1 \%$ formic acid) 50:50 ratio. The purity of all the compounds tested using this method were $\geq 95 \%$.

HPLC method D: column: ACE 5 C18 $(150 \times 3 \mathrm{~mm}$ i.d.); eluent: isocratic: water $(0.1 \%$ formic acid $)$ - methanol (0.1\% formic acid) 20:80 ratio. The purity of all the compounds tested using this method were $\geq 95 \%$.

Prep HPLC method A: column: Vydac protein and peptide 218TP510; eluent: gradient: water ( $0.1 \%$ formic acid) - methanol ( $0.1 \%$ formic acid) $(0-90 \%)$.

Methyl-(2S or R)-2-\{[(benzyloxy)carbonyl]amino\}propanoate (6a) [29]: Cbz-L/D-alanine 5a (10.0 g, $45.0 \mathrm{mmol})$ was esterified and worked up using general method $\mathrm{A}$, yielding the desired product as a white powder $(10.6 \mathrm{~g}, 99 \%)$. The reaction and the work up were monitored by TLC (eluent: petroleum ether $\left(40-60^{\circ} \mathrm{C}\right)$ - ethyl acetate, $2: 1$ ratio, $\mathrm{R}_{\mathrm{f}}: 0.51$ ). Mp: $41-43{ }^{\circ} \mathrm{C}$ (literature: $43-44{ }^{\circ} \mathrm{C}$, light petrol)[30]; ${ }^{1} \mathrm{H}-\mathrm{NMR}$ $\left(300 \mathrm{MHz}\right.$, DMSO- $\left.d_{6}\right) \delta_{\mathrm{H}} 7.74(1 \mathrm{H}, \mathrm{d}, J=7.5 \mathrm{~Hz}, 5-\mathrm{H}), 7.34(5 \mathrm{H}, \mathrm{m}, 9,10,11-\mathrm{H}), 5.03(2 \mathrm{H}, \mathrm{s}, 7-\mathrm{H}), 4.11(1 \mathrm{H}$, quint, $J=7.5 \mathrm{~Hz}, 2-\mathrm{H}), 3.63(3 \mathrm{H}, \mathrm{s}, 4-\mathrm{H}), 1.27(3 \mathrm{H}, \mathrm{d}, J=7.2 \mathrm{~Hz}, 3-\mathrm{H}) ;{ }^{13} \mathrm{C}-\mathrm{NMR}\left(75.5 \mathrm{MHz}, \mathrm{DMSO}-d_{6}\right)$ $\delta_{C} 173.8(1-C), 156.3(6-C), 137.4(8-C), 128.8$ (2C, 10-C), 128.3 (11-C), 128.2 (2C, 9-C), 65.9 (7-C), 52.3 (4-C), $49.8(2-\mathrm{C}), 17.4(3-\mathrm{C}) ; v_{\max } / \mathrm{cm}^{-1} 3335(\mathrm{~N}-\mathrm{H}), 1703(\mathrm{C}=\mathrm{O}), 1668(\mathrm{C}=\mathrm{O}), 1524(\mathrm{~N}-\mathrm{H}), 1209$ (C-O); MS(ESI) $m / z 260.1(\mathrm{M}+\mathrm{Na})^{+}$.

Benzyl-N-[(1S or R)-1-carbamoylethyl]carbamate (7a) [9]: Cbz-L/D-alanine methyl ester 6a (10.0 g, $42 \mathrm{mmol})$ was reacted and worked up using general method B, to give the product as a white powder $(9.40 \mathrm{~g}$, $99 \%)$. The reaction and the work up were monitored by TLC (eluent: petroleum ether $\left(40-60{ }^{\circ} \mathrm{C}\right)$ - 
ethyl acetate, 1:1 ratio, $\left.\mathrm{R}_{\mathrm{f}}: 0.11\right)$. Mp: $131-132{ }^{\circ} \mathrm{C}$ (literature: $130-131{ }^{\circ} \mathrm{C}$, methanol-diethyl ether)[31]; ${ }^{1} \mathrm{H}-\mathrm{NMR}\left(300 \mathrm{MHz}, \mathrm{DMSO}-d_{6}\right) \delta_{\mathrm{H}} 7.35(6 \mathrm{H}, \mathrm{m}, 5,9,10,11-\mathrm{H}), 7.26\left(1 \mathrm{H}, \mathrm{s}, 4-\mathrm{H}_{\mathrm{a}}\right), 6.93\left(1 \mathrm{H}, \mathrm{s}, 4-\mathrm{H}_{\mathrm{b}}\right)$, $5.02(2 \mathrm{H}, \mathrm{s}, 7-\mathrm{H}), 3.98(1 \mathrm{H}$, quint, $J=7.2 \mathrm{~Hz}, 2-\mathrm{H}), 1.21(3 \mathrm{H}, \mathrm{d}, J=7.2 \mathrm{~Hz}, 3-\mathrm{H}) ;{ }^{13} \mathrm{C}-\mathrm{NMR}(75.5 \mathrm{MHz}$, DMSO- $\left.d_{6}\right) \delta_{\mathrm{C}} 174.9$ (1-C), $156.1(6-\mathrm{C}), 137.5$ (8-C), 128.76 (2C, 10-C), 128.2 (11-C), 128.1 (2C, 9-C), 65.8 (7-C), $50.4(2-\mathrm{C}), 18.7(3-\mathrm{C}) ; v_{\max } / \mathrm{cm}^{-1} 3386(\mathrm{~N}-\mathrm{H}), 3308(\mathrm{~N}-\mathrm{H}), 3196(\mathrm{~N}-\mathrm{H}), 1651(\mathrm{C}=\mathrm{O}), 1537(\mathrm{~N}-\mathrm{H})$, 1247 (C-O); MS(ESI) $m / z 223.1(\mathrm{M}+\mathrm{H})^{+}$.

Benzyl-N-[(1S or R)-1-cyanoethyl]carbamate (8a) [9]: Cbz-L/D-alanine amide 7a (3.48 g, $15.7 \mathrm{mmol})$ was reacted and worked up using general method $C$. The crude product was washed with heptane to give the product as white crystals $(3.12 \mathrm{~g}, 97 \%)$. The reaction and the work up were monitored by TLC (eluent: petroleum ether $\left(40-60^{\circ} \mathrm{C}\right)$ - ethyl acetate $1: 1$ ratio, $\left.\mathrm{R}_{\mathrm{f}}: 0.41\right) . \mathrm{Mp}: 79-80^{\circ} \mathrm{C}$ (literature: $\left.82-83{ }^{\circ} \mathrm{C}[32]\right) ;{ }^{1} \mathrm{H}-\mathrm{NMR}\left(300 \mathrm{MHz}, \mathrm{DMSO}-d_{6}\right) \delta_{\mathrm{H}} 8.14(1 \mathrm{H}, \mathrm{d}, J=5.4 \mathrm{~Hz}, 4-\mathrm{H}), 7.37(5 \mathrm{H}, \mathrm{m}, 8,9,10-\mathrm{H})$, $5.08(2 \mathrm{H}, \mathrm{s}, 6-\mathrm{H}), 4.59(1 \mathrm{H}$, quint, $J=7.2 \mathrm{~Hz}, 2-\mathrm{H}), 1.43(3 \mathrm{H}, \mathrm{d}, J=7.2 \mathrm{~Hz}, 3-\mathrm{H}) ;{ }^{13} \mathrm{C}-\mathrm{NMR}(75.5 \mathrm{MHz}$, DMSO- $\left.d_{6}\right) \delta_{C} 155.7$ (5-C), 137.0 (7-C), 128.9 (9-C), 128.5 (10-C), 128.4 (8-C), 120.9 (1-C), 66.5 (6-C), 38.2 (2-C), $18.8(3-\mathrm{C}) ; v_{\max } / \mathrm{cm}^{-1} 3332(\mathrm{~N}-\mathrm{H}), 2356(\mathrm{C} \equiv \mathrm{N}), 1686(\mathrm{C}=\mathrm{O}), 1521(\mathrm{~N}-\mathrm{H}), 1253(\mathrm{C}-\mathrm{O}) ; \mathrm{MS}(\mathrm{ESI}) \mathrm{m} / \mathrm{z}$ $227.1(\mathrm{M}+\mathrm{Na})^{+}$.

Benzyl-N-[(1S or R)-1-(1H-1,2,3,4-tetrazol-5-yl)ethyl]carbamate (9a) [9]: Cbz-L/D-alanyl nitrile (8a, $7.80 \mathrm{~g}$, $38.0 \mathrm{mmol}$ ) was reacted and worked up using general method $\mathrm{D}$. The product was gained as a white solid $(7.55 \mathrm{~g}, 80 \%)$. The reaction and the work up were monitored by TLC (eluent: petroleum ether (40-60 ${ }^{\circ} \mathrm{C}$ ) - ethyl acetate 1:1, $\left.\mathrm{R}_{\mathrm{f}}: 0.09\right)$. Mp: $134-138^{\circ} \mathrm{C}$ (literature: $\left.139-141^{\circ} \mathrm{C}[33]\right) ;{ }^{1} \mathrm{H}-\mathrm{NMR}(300 \mathrm{MHz}$, DMSO- $\left.d_{6}\right) \delta_{\mathrm{H}} 7.99(1 \mathrm{H}, \mathrm{d}, J=6.9 \mathrm{~Hz}, 4-\mathrm{H}), 7.33(5 \mathrm{H}, \mathrm{m}, 9,10,11-\mathrm{H}), 5.01(3 \mathrm{H}, \mathrm{m}, 2,7-\mathrm{H}), 1.49(3 \mathrm{H}, \mathrm{d}$, $J=7,2 \mathrm{~Hz}, 3-\mathrm{H}) ;{ }^{13} \mathrm{C}-\mathrm{NMR}\left(75.5 \mathrm{MHz}, \mathrm{DMSO}-d_{6}\right) \delta_{\mathrm{C}} 158.6$ (1-C), 155.7 (6-C), 136.8 (8-C), 128.31 (2C, 10-C), 127.8 (3C, 9,11-C), 65.7 (7-C), 41.9 (2-C), 19.3 (3-C); $v_{\max } / \mathrm{cm}^{-1} 3308(\mathrm{~N}-\mathrm{H}), 2980,2866,2738,2614$ (tetrazole), $1686(\mathrm{C}=\mathrm{O}), 1524(\mathrm{~N}-\mathrm{H}), 1255(\mathrm{C}-\mathrm{O})$; MS(ESI) $\mathrm{m} / \mathrm{z} 248.1(\mathrm{M}+\mathrm{H})^{+}$.

(1S or R)-1-(1H-1,2,3,4-tetrazol-5-yl)ethan-1-amine (4a) [9]: Cbz-L/D-aminoethyltetrazole (9a, $0.75 \mathrm{~g}$, $3.0 \mathrm{mmol}$ ) was deprotected using general method E. Following filtration, the solid residue was washed with ethanol and the filtrate was evaporated under reduced pressure to give the product as a white solid $(0.33 \mathrm{~g}, 97 \%)$. The reaction and the work up were monitored by TLC (eluent: ethyl acetate ethanol 8:1 ratio, $\mathrm{R}_{\mathrm{f}}$ : 0.03). Mp: $230{ }^{\circ} \mathrm{C}$ (decomposed) (literature: $268-270{ }^{\circ} \mathrm{C}$, (decomposed) [9]). ${ }^{1} \mathrm{H}-\mathrm{NMR}\left(300 \mathrm{MHz}, \mathrm{DMSO}-d_{6}\right) \delta_{\mathrm{H}} 4.55(1 \mathrm{H}$, quart, $J=6.6 \mathrm{~Hz}, 2-\mathrm{H}), 1.54(3 \mathrm{H}, \mathrm{d}, J=6.9 \mathrm{~Hz}, 3-\mathrm{H})$; ${ }^{13} \mathrm{C}-\mathrm{NMR}\left(75.5 \mathrm{MHz}, \mathrm{DMSO}-d_{6}\right) \delta_{\mathrm{C}} 160.4(1-\mathrm{C}), 44.1(2-\mathrm{C}), 19.8(3-\mathrm{C}) ; v_{\max } / \mathrm{cm}^{-1} 3388(\mathrm{~N}-\mathrm{H}), 2916,2719$, 2634, 2522 (tetrazole); MS(ESI) $m / z 114.1(\mathrm{M}+\mathrm{H})^{+}$.

Methyl-(2S)-2-\{[(benzyloxy)carbonyl]amino\}butanoate (6b-L) [34]: Cbz-L-ethylglycine (5b-L, $5.0 \mathrm{~g}$, $21.0 \mathrm{mmol}$ ) was reacted and worked up using general method A, yielding the product as colourless oil $(5.1 \mathrm{~g}, 97 \%)$. The reaction and the work up were monitored by TLC (eluent: petroleum ether $\left(40-60^{\circ} \mathrm{C}\right)$ - ethyl acetate, 2:1 ratio, $\left.\mathrm{R}_{\mathrm{f}}: 0.77\right) .{ }^{1} \mathrm{H}-\mathrm{NMR}\left(300 \mathrm{MHz}, \mathrm{DMSO}-d_{6}\right) \delta_{\mathrm{H}} 7.69(1 \mathrm{H}, \mathrm{d}, J=7.5 \mathrm{~Hz}, 6-\mathrm{H}), 7.36$ $(5 \mathrm{H}, \mathrm{m}, 10,11,12-\mathrm{H}), 5.04(2 \mathrm{H}, \mathrm{s}, 8-\mathrm{H}), 3.97(1 \mathrm{H}, \mathrm{td}, J=5.4, J=8.4 \mathrm{~Hz}, 2-\mathrm{H}), 3.63(1 \mathrm{H}, \mathrm{s}, 5-\mathrm{H}), 1.66(2 \mathrm{H}$, $\mathrm{m}, 3-\mathrm{H}), 0.89(3 \mathrm{H}, \mathrm{t}, J=7.2 \mathrm{~Hz}, 4-\mathrm{H}) ;{ }^{13} \mathrm{C}-\mathrm{NMR}\left(75.5 \mathrm{MHz}, \mathrm{DMSO}-d_{6}\right) \delta_{\mathrm{C}} 173.2$ (1-C), 156.6 (7-C), 137.4 (9-C), 128.8 (11-C), 128.3 (12-C), 128.2 (10-C), 65.9 (8-C), 55.8 (2-C), 52.2 (5-C), 24.6 (3-C), 10.9 (4-C); $v_{\max } / \mathrm{cm}^{-1} 3345(\mathrm{~N}-\mathrm{H}), 1703(\mathrm{C}=\mathrm{O}), 1520(\mathrm{~N}-\mathrm{H}), 1206(\mathrm{C}-\mathrm{O}) ; \mathrm{MS}(\mathrm{ESI}) \mathrm{m} / \mathrm{z} 250.8(\mathrm{M}-\mathrm{H})^{-}$.

Benzyl-N-[(1S)-1-carbamoylpropyl]carbamate (7b-L) [35]: Cbz-L-ethylglycine methyl ester (6b-L, 2.0 g, $8.0 \mathrm{mmol}$ ) was reacted and worked up using general method B. The crude product was washed with diethyl ether to give the product as white crystals $(1.72 \mathrm{~g}, 91 \%)$. The reaction and the work up were monitored by TLC (eluent: petroleum ether $\left(40-60^{\circ} \mathrm{C}\right)$ - ethyl acetate, $1: 1$ ratio, $\mathrm{R}_{\mathrm{f}}$ : 0.07$)$. Mp: 140-142 ${ }^{\circ} \mathrm{C}$ (literature: $\left.141{ }^{\circ} \mathrm{C}[36]\right) ;{ }^{1} \mathrm{H}-\mathrm{NMR}\left(300 \mathrm{MHz}\right.$, DMSO- $\left.d_{6}\right) \delta_{\mathrm{H}} 7.36(5 \mathrm{H}, \mathrm{m}, 10,11,12-\mathrm{H}), 7.29$ $(1 \mathrm{H}, \mathrm{s}, 5 \mathrm{a}-\mathrm{H}), 7.20(1 \mathrm{H}, \mathrm{d}, J=8.4 \mathrm{~Hz}, 6-\mathrm{H}), 6.95(1 \mathrm{H}, \mathrm{s}, 5 \mathrm{~b}-\mathrm{H}), 5.03(2 \mathrm{H}, \mathrm{s}, 8-\mathrm{H}), 3.87(1 \mathrm{H}, \mathrm{td}, J=5.4, J=$ $8.4 \mathrm{~Hz}, 2 \mathrm{H}), 1.67(1 \mathrm{H}, \mathrm{m}, 3 \mathrm{a}-\mathrm{H}), 1.55(1 \mathrm{H}, \mathrm{m}, 3 \mathrm{~b}-\mathrm{H}), 0.86(3 \mathrm{H}, \mathrm{t}, J=7.2 \mathrm{~Hz}, 4-\mathrm{H}) ;{ }^{13} \mathrm{C}-\mathrm{NMR}(75.5 \mathrm{MHz}$, DMSO- $d_{6}$ ) $\delta_{C}$ 174. 2 (1-C), 156.4 (7-C), 137.6 (9-C), 128.8 (11-C), 128.2 (12-C), 128.1 (10-C), 65.8 (8-C), 
56.3 (2-C), $25.6(3-\mathrm{C}), 10.8(4-\mathrm{C}) ; v_{\max } / \mathrm{cm}^{-1} 3380(\mathrm{~N}-\mathrm{H}), 3308(\mathrm{~N}-\mathrm{H}), 3196(\mathrm{~N}-\mathrm{H}), 1649(\mathrm{C}=\mathrm{O}), 1535$ (N-H), $1240(\mathrm{C}-\mathrm{O}) ; \mathrm{MS}(\mathrm{ESI}) \mathrm{m} / z 237.1(\mathrm{M}+\mathrm{H})^{+}$.

Benzyl-N-[(1S)-1-cyanopropyl]carbamate (8b-L) [37]: Cbz-L-ethylglycine amide (7b-L, 4.25 g, 18.0 mmol) was reacted and worked up using general method $\mathrm{C}$ to give the product as white crystals $(3.88 \mathrm{~g}, 99 \%)$. The reaction and the work up were monitored by TLC (eluent: petroleum ether $\left(40-60^{\circ} \mathrm{C}\right)$ - ethyl acetate $1: 2$ ratio, $\left.\mathrm{R}_{\mathrm{f}}: 0.64\right)$. Mp: $43-45{ }^{\circ} \mathrm{C} ;{ }^{1} \mathrm{H}-\mathrm{NMR}\left(300 \mathrm{MHz}, \mathrm{DMSO}-d_{6}\right) \delta_{\mathrm{H}} 8.15(1 \mathrm{H}, \mathrm{d}, J=7.8 \mathrm{~Hz}$, $5-\mathrm{H}), 7.37(5 \mathrm{H}, \mathrm{m}, 9,10,11-\mathrm{H}), 5.09(2 \mathrm{H}, \mathrm{s}, 7-\mathrm{H}), 4.48(1 \mathrm{H}$, quart, $J=7.8 \mathrm{~Hz}, 2-\mathrm{H}), 1.78(2 \mathrm{H}$, pentd, $J=1.5$, $J=7.5 \mathrm{~Hz}, 3-\mathrm{H}), 0.96(3 \mathrm{H}, \mathrm{t}, J=7.2 \mathrm{~Hz}, 4-\mathrm{H}) ;{ }^{13} \mathrm{C}-\mathrm{NMR}\left(75.5 \mathrm{MHz}, \mathrm{DMSO}-d_{6}\right) \delta_{\mathrm{C}} 156.0(6-\mathrm{C}), 137.0(8-\mathrm{C})$, 128.9 (10-C), 128.5 (11-C), 128.5 (9-C), 120.1 (1-C), 66.6 (7-C), 44.2 (2-C), 25.8 (3-C), $10.3(4-C) ; v_{\max } / \mathrm{cm}^{-1}$ $3312(\mathrm{~N}-\mathrm{H}), 1694(\mathrm{C}=\mathrm{O}), 1524(\mathrm{~N}-\mathrm{H}), 1263(\mathrm{C}-\mathrm{O}) ; \mathrm{MS}(\mathrm{ESI}) \mathrm{m} / \mathrm{z} 219.1(\mathrm{M}+\mathrm{H})^{+}$.

Benzyl-N-[(1S)-1-(1H-1,2,3,4-tetrazol-5-yl)propyl]carbamate (9b-L) [38]: Cbz-L-ethylglycyl nitrile (8b-L, $3.9 \mathrm{~g}, 18 \mathrm{mmol}$ ) was reacted and worked up using general method D. The product was gained as a white solid $(3.83 \mathrm{~g}, 81 \%)$. The reaction and the work up were monitored by TLC (eluent: petroleum ether $\left(40-60{ }^{\circ} \mathrm{C}\right)$ - ethyl acetate 1:2, $\left.\mathrm{R}_{\mathrm{f}}: 0.20\right)$. Mp: $142-144{ }^{\circ} \mathrm{C} ;{ }^{1} \mathrm{H}-\mathrm{NMR}\left(300 \mathrm{MHz}\right.$, DMSO- $\left.d_{6}\right) \delta_{\mathrm{H}} 7.98$ $(1 \mathrm{H}, \mathrm{d}, J=7.2 \mathrm{~Hz}, 6-\mathrm{H}), 7.36(5 \mathrm{H}, \mathrm{m}, 10,11,12-\mathrm{H}), 5.08(1 \mathrm{H}, \mathrm{d}, J=12.3 \mathrm{~Hz}, 8 \mathrm{a}-\mathrm{H}), 5.02(1 \mathrm{H}, \mathrm{d}, J=12.6 \mathrm{~Hz}$, $8 \mathrm{~b}-\mathrm{H}), 4.83(1 \mathrm{H}$, quart, $J=8.1 \mathrm{~Hz}, 2-\mathrm{H}), 1.89(2 \mathrm{H}, \mathrm{m}, 3-\mathrm{H}), 0.89(3 \mathrm{H}, \mathrm{t}, J=7.2 \mathrm{~Hz}, 4-\mathrm{H}) ;{ }^{13} \mathrm{C}-\mathrm{NMR}$ $\left(75.5 \mathrm{MHz}, \mathrm{DMSO}-d_{6}\right) \delta_{\mathrm{C}} 158.4(1-\mathrm{C}), 156.4$ (7-C), 137.3 (9-C), 128.8 (11-C), 128.3 (12-C), 128.2 (10-C), $66.1(8-\mathrm{C}), 48.2(2-\mathrm{C}), 26.7(3-\mathrm{C}), 10.7(4-\mathrm{C}) ; v_{\max } / \mathrm{cm}^{-1} 3296(\mathrm{~N}-\mathrm{H}), 2976,2880,2714,2615$, (tetrazole), $1686(\mathrm{C}=\mathrm{O}), 1528(\mathrm{~N}-\mathrm{H}), 1263(\mathrm{C}-\mathrm{O}) ; \mathrm{MS}(\mathrm{ESI}) \mathrm{m} / \mathrm{z} 262.1(\mathrm{M}+\mathrm{H})^{+}$.

(1S)-1-(1H-1,2,3,4-tetrazol-5-yl)propane-1-amine (4b-L) [39]: Cbz-L-aminopropyltetrazole (9b-L, 3.72 g, $14.0 \mathrm{mmol}$ ) was deprotected using general method E. Following filtration, the solid residue was washed with ethanol and the filtrate was evaporated under reduced pressure to give the crude, which was washed to gain the pure product as a white solid $(1.60 \mathrm{~g}, 88 \%)$. The reaction and the work up were monitored by TLC (eluent: ethanol, $\mathrm{R}_{\mathrm{f}}: 0.18$ ). $\mathrm{Mp}: 260^{\circ} \mathrm{C}$, decomposed (literature: $273-274{ }^{\circ} \mathrm{C}$ [39]). ${ }^{1} \mathrm{H}-\mathrm{NMR}\left(300 \mathrm{MHz}, \mathrm{D}_{2} \mathrm{O}\right) \delta_{\mathrm{H}} 4.62(1 \mathrm{H}, \mathrm{t}, J=7.2 \mathrm{~Hz}, 2-\mathrm{H}), 2.05(2 \mathrm{H}$, quint, $J=7.5 \mathrm{~Hz}, 3-\mathrm{H}), 0.82(3 \mathrm{H}, \mathrm{t}$, $J=7.5 \mathrm{~Hz}, 4-\mathrm{H}) ;{ }^{13} \mathrm{C}-\mathrm{NMR}\left(75.5 \mathrm{MHz}, \mathrm{D}_{2} \mathrm{O}\right) \delta_{\mathrm{C}} 159.6(1-\mathrm{C}), 48.7(2-\mathrm{C}), 26.0(3-\mathrm{C}), 8.9(4-\mathrm{C}) ; \gamma_{\max } / \mathrm{cm}^{-1}$ 2820, 2716, 2613, 2561 (tetrazole), $1530(\mathrm{~N}-\mathrm{H})$; MS(ESI) $\mathrm{m} / \mathrm{z} 128.1(\mathrm{M}+\mathrm{H})^{+}$.

9H-Fluoren-9-ylmethyl-N-[(1S or R)-1-(1H-1,2,3,4-tetrazol-5-yl)ethyl]carbamate (10a) [40]: L/D-1Aminoethyltetrazole (4a, $2.00 \mathrm{~g}, 17.7 \mathrm{mmol})$ was reacted using general method F. The crude product was purified by recrystallization from acetonitrile to give the pure product as white crystals $(0.92 \mathrm{~g}$, $56 \%$ ). The reaction and the work up was monitored by TLC (eluent: dichloromethane - ethanol 20:1 ratio, $\mathrm{R}_{\mathrm{f}}:$ 0.07). Mp: $197-199{ }^{\circ} \mathrm{C}$ (literature: $200-202{ }^{\circ} \mathrm{C}$ (decomposed) [40]); ${ }^{1} \mathrm{H}-\mathrm{NMR}(300 \mathrm{MHz}$, DMSO- $\left.d_{6}\right) \delta_{\mathrm{H}} 8.05(1 \mathrm{H}, \mathrm{d}, J=7.5 \mathrm{~Hz}, 4-\mathrm{H}), 7.88(2 \mathrm{H}, \mathrm{d}, J=7.5 \mathrm{~Hz}, 13-\mathrm{H}), 7.71(2 \mathrm{H}, \mathrm{t}, J=6.6 \mathrm{~Hz}, 10-\mathrm{H})$, $7.41(2 \mathrm{H}, \mathrm{t}, J=7.2 \mathrm{~Hz}, 12-\mathrm{C}), 7.31(2 \mathrm{H}, \mathrm{m}, 11-\mathrm{H}), 5.01(1 \mathrm{H}$, quint, $J=7.2 \mathrm{~Hz}, 2-\mathrm{H}), 4.32(1 \mathrm{H}, \mathrm{m}, 8-\mathrm{H}), 4.24$ $(2 \mathrm{H}, \mathrm{m}, 7-\mathrm{H}), 1.51(3 \mathrm{H}, \mathrm{d}, J=6.9 \mathrm{~Hz}, 3-\mathrm{H}) ;{ }^{13} \mathrm{C}-\mathrm{NMR}\left(75.5 \mathrm{MHz}, \mathrm{DMSO}-d_{6}\right) \delta_{\mathrm{C}} 159.0(1-\mathrm{C}), 156.0(6-\mathrm{C})$, 144.3 (9a-C), 144.2 (9b-C), 141.2 (14-C), 128.1 (12-C), 127.5 (11-C), 125.7 (10-C), 120.6 (13-C), 66.2 (7-C), $47.1(8-\mathrm{C}), 42.3(2-\mathrm{C}), 19.8(3-\mathrm{C}) ; v_{\max } / \mathrm{cm}^{-1} 3310(\mathrm{~N}-\mathrm{H}), 2965,2868,2740,2617$ (tetrazole), $1686(\mathrm{C}=\mathrm{O})$, $1523(\mathrm{~N}-\mathrm{H}), 1258(\mathrm{C}-\mathrm{O}) ; \mathrm{MS}(\mathrm{ESI}) \mathrm{m} / z 336.2(\mathrm{M}+\mathrm{H})^{+}$.

9H-Fluoren-9-ylmethyl-N-[(1S)-1-(1H-1,2,3,4-tetrazol-5-yl)propyl]carbamate (10b-L): L-1-Amino-ethyltetrazole $(4 \mathrm{~b}-\mathrm{L}, 1.79 \mathrm{~g}, 6.9 \mathrm{mmol})$ was reacted using general method $\mathrm{F}$. The crude product was purified by recrystallization in 2 generations from acetonitrile to give the pure product as white crystals $(1.66 \mathrm{~g}, 75 \%)$. The reaction and the work up were monitored by TLC (eluent: dichloromethane - ethanol 10:1 ratio, $\mathrm{R}_{\mathrm{f}}$ : 0.21). Mp: $209-211^{\circ} \mathrm{C}$ (melted and decomposed); ${ }^{1} \mathrm{H}-\mathrm{NMR}\left(300 \mathrm{MHz}, \mathrm{DMSO}-d_{6}\right) \delta_{\mathrm{H}} 16.26(6-\mathrm{H}), 8.04(1 \mathrm{H}$, $\mathrm{d}, J=7.8 \mathrm{~Hz}, 5-\mathrm{H}), 7.89(2 \mathrm{H}, \mathrm{d}, J=7.5 \mathrm{~Hz}, 14-\mathrm{H}), 7.72(2 \mathrm{H}, \mathrm{t}, J=7.2 \mathrm{~Hz}, 11-\mathrm{H}), 7.42(2 \mathrm{H}, \mathrm{t}, J=7.5 \mathrm{~Hz}, 13-\mathrm{H})$, $7.33(2 \mathrm{H}, \mathrm{m}, 12-\mathrm{H}), 4.81(1 \mathrm{H}$, quart, $J=8.1 \mathrm{~Hz}, 2-\mathrm{H}), 4.34(2 \mathrm{H}, \mathrm{m}, 8-\mathrm{H}), 4.23(1 \mathrm{H}, \mathrm{m}, 9-\mathrm{H}), 1.91(2 \mathrm{H}, \mathrm{m}, 3-\mathrm{H})$, $0.88(3 \mathrm{H}, \mathrm{t}, J=7.2 \mathrm{~Hz}, 4-\mathrm{H}){ }^{13} \mathrm{C}-\mathrm{NMR}\left(75.5 \mathrm{MHz}, \mathrm{DMSO}-d_{6}\right) \delta_{\mathrm{C}} 156.4(7-\mathrm{C}), 144.3(10 \mathrm{a}-\mathrm{C}), 144.2(10 \mathrm{~b}-\mathrm{C})$, 141.2 (15-C), 128.1 (13-C), 127.5 (12-C), 125.7 (11-C), 120.6 (14-C), 66.2 (8-C), 48.1 (2-C), 47.1 (9-C), 26.6 (3-C), $10.7(4-\mathrm{C}) ; \nu_{\max } / \mathrm{cm}^{-1} 3300(\mathrm{~N}-\mathrm{H}), 2978,2876,2717,2617$ (tetrazole), $1682(\mathrm{C}=\mathrm{O}), 1533(\mathrm{~N}-\mathrm{H}), 1265(\mathrm{C}-\mathrm{O})$; 
MS(ESI) $m / z 350.1(\mathrm{M}+\mathrm{H})^{+}$; $\mathrm{CHN}$ [Found: $\mathrm{C}, 65.08 ; \mathrm{H}, 5.53 ; \mathrm{N}, 19.86 . \mathrm{C}_{19} \mathrm{H}_{19} \mathrm{~N}_{5} \mathrm{O}_{2}$ requires $\mathrm{C}, 65.32 ; \mathrm{H}$, $5.48 ; \mathrm{N}, 19.86 \%]$.

Benzyl-N-(\{[(1S)-1-(1H-1,2,3,4-tetrazol-5-yl)ethyl]carbamoyl\}methyl)carbamate (13g-L): Prepared using general method G. The Fmoc group of Fmoc-1-L-aminoethyltetrazole attached to 2-chlorotrityl chloride resin (resin:loading; 1:1 ratio; $1.3 \mathrm{mmol}$ ) was removed, this was monitored by the Fmoc and TNBS tests. After the coupling of Cbz-glycine with the resin, the title compound was cleaved off. The cleaving mixture (TFA/DCM/TIS, ratio 5:95:1 eq) was removed by evaporation under reduced pressure. The residue washed with petroleum ether $\left(40-60^{\circ} \mathrm{C}\right)$ to obtain the product as white crystals $(0.24 \mathrm{~g}, 59 \%)$. The reaction and the work up were monitored by TLC (eluent: ethanol, $\left.\mathrm{R}_{\mathrm{f}}: 0.56\right)$. Mp: 134-136 ${ }^{\circ} \mathrm{C} ;{ }^{1} \mathrm{H}-\mathrm{NMR}\left(300 \mathrm{MHz}\right.$, DMSO- $\left.d_{6}\right) \delta_{\mathrm{H}} 8.56(1 \mathrm{H}, \mathrm{d}, J=7.2 \mathrm{~Hz}, 4-\mathrm{H}), 7.35(6 \mathrm{H}, \mathrm{m}, 7,12,13,14-\mathrm{H})$, $5.24(1 \mathrm{H}$, quint, $J=7.2 \mathrm{~Hz}, 2-\mathrm{H}), 5.03(2 \mathrm{H}, \mathrm{s}, 10-\mathrm{H}), 3.68(2 \mathrm{H}, \mathrm{d}, J=6.3 \mathrm{~Hz}, 6-\mathrm{H}), 1.49(3 \mathrm{H}, \mathrm{d}, J=6.9 \mathrm{~Hz}$, 3-H); ${ }^{13} \mathrm{C}-\mathrm{NMR}\left(75.5 \mathrm{MHz}, \mathrm{DMSO}-d_{6}\right) \delta_{\mathrm{C}} 169.3(5-\mathrm{C}), 158.9$ (1-C), 156.9 (9-C), 137.5 (11-C), 128.8 (13-C), 128.2 (14-C), 128.1 (12-C), 65.9 (10-C), 43.8 (6-C), $40.3(2-\mathrm{C}), 19.8$ (3-C); $v_{\max } / \mathrm{cm}^{-1} 3289(\mathrm{~N}-\mathrm{H}), 3269$ $(\mathrm{N}-\mathrm{H}), 1697(\mathrm{C}=\mathrm{O}), 1661(\mathrm{C}=\mathrm{O}), 1530(\mathrm{~N}-\mathrm{H}), 1244(\mathrm{C}-\mathrm{O})$; MS(ESI) $\mathrm{m} / \mathrm{z} 305.1(\mathrm{M}+\mathrm{H})^{+}$; HRMS (Found $(\mathrm{M}+\mathrm{H})^{+}$305.1360. Calcd. for $\mathrm{C}_{13} \mathrm{H}_{17} \mathrm{O}_{3} \mathrm{~N}_{6}:(\mathrm{M}+\mathrm{H})^{+}$305.1357.); (Purity test: HPLC method D).

2-Amino-N-[(1S)-1-(1H-1,2,3,4-tetrazol-5-yl)ethyl]acetamide (14g-L): Cbz-glycyl-1-L-aminoethyl-tetrazole (13g-L, $0.18 \mathrm{~g}, 0.57 \mathrm{mmol})$ was deprotected by general method E. Following filtration, the solid residue was washed with $30 \mathrm{~mL}$ methanol, which was discarded. The solid residue was washed into a separate flask with water, which was freeze dried to give the product as a white solid $(0.01 \mathrm{~g}, 99 \%)$. Further purification was performed by Prep HPLC method A. Mp: $180{ }^{\circ} \mathrm{C}$ (decomposed); ${ }^{1} \mathrm{H}-\mathrm{NMR}(300 \mathrm{MHz}$, $\left.\mathrm{D}_{2} \mathrm{O}\right) \delta_{\mathrm{H}} 5.27(1 \mathrm{H}$, quart, $J=6.9 \mathrm{~Hz}, 2-\mathrm{H}), 3.75(2 \mathrm{H}, \mathrm{s}, 6-\mathrm{H}), 1.52(3 \mathrm{H}, \mathrm{d}, J=6.9 \mathrm{~Hz}, 3-\mathrm{H}) ;{ }^{13} \mathrm{C}-\mathrm{NMR}$ (75.5 MHz, $\left.\mathrm{D}_{2} \mathrm{O}\right) \delta_{\mathrm{C}} 167.3(5-\mathrm{C}), 164.3(1-\mathrm{C}), 42.3(2-\mathrm{C}), 41.0(6-\mathrm{C}), 19.3(3-\mathrm{C}) ; v_{\max } / \mathrm{cm}^{-1} 3215(\mathrm{~N}-\mathrm{H})$, $1672(\mathrm{C}=\mathrm{O}) 1547(\mathrm{~N}-\mathrm{H})$; MS(ESI) $\mathrm{m} / z 171.1(\mathrm{M}+\mathrm{H})^{+}$; HRMS (Found $(\mathrm{M}+\mathrm{H})^{+}$171.0987. Calcd. for $\mathrm{C}_{5} \mathrm{H}_{11} \mathrm{ON}_{6}:(\mathrm{M}+\mathrm{H})^{+}$171.0989.); (Purity test: HPLC method A).

Benzyl-N-[(1S)-1-\{[(1S)-1-(1H-1,2,3,4-tetrazol-5-yl)ethyl]carbamoyl\}ethyl]carbamate (13a-LL): Prepared using general method G. The Fmoc group of Fmoc-1-L-aminoethyltetrazole attached to 2-chlorotrityl chloride resin (resin:loading; 1:1 ratio; $1.3 \mathrm{mmol}$ ) was removed, this was monitored by the Fmoc and TNBS tests. After the coupling of Cbz-L-alanine with the resin, the title compound was cleaved off. The cleaving mixture (TFA/DCM/TIS, ratio 5:95:1 eq) was removed by evaporation under reduced pressure and washed with petroleum ether $\left(40-60^{\circ} \mathrm{C}\right)$ to obtain the product as white crystals $(0.23 \mathrm{~g}$, $58 \%$ ). The reaction and the work up were monitored by TLC (eluent: ethyl acetate and 1 drop of glacial acetic acid, $\mathrm{R}_{\mathrm{f}}$ : 0.07). Mp: $186-187^{\circ} \mathrm{C} ;{ }^{1} \mathrm{H}-\mathrm{NMR}\left(300 \mathrm{MHz}, \mathrm{DMSO}-\mathrm{d}_{6}\right) \delta_{\mathrm{H}} 16.18(1 \mathrm{H}, \mathrm{br} \mathrm{s}, 9-\mathrm{H}), 8.54(1 \mathrm{H}$, $\mathrm{d}, J=7.5 \mathrm{~Hz}, 4-\mathrm{H}), 7.35(6 \mathrm{H}, \mathrm{m}, 8,13-15-\mathrm{H}), 5.23(1 \mathrm{H}$, quint $J=7.2 \mathrm{~Hz}, 2-\mathrm{H}), 5.05(1 \mathrm{H}, \mathrm{d}, J=12.6 \mathrm{~Hz}$, $\left.11-\mathrm{H}_{\mathrm{a}}\right), 5.00\left(1 \mathrm{H}, \mathrm{d}, J=12.6 \mathrm{~Hz}, 11-\mathrm{H}_{\mathrm{b}}\right), 4.09(1 \mathrm{H}$, quint, $J=7.2 \mathrm{~Hz}, 6-\mathrm{H}), 1.50(3 \mathrm{H}, \mathrm{d}, J=7.2 \mathrm{~Hz}, 3-\mathrm{H})$, $1.20(3 \mathrm{H}, \mathrm{d}, J=7.2 \mathrm{~Hz}, 7-\mathrm{H}) ;{ }^{13} \mathrm{C}-\mathrm{NMR}\left(75.5 \mathrm{MHz}, \mathrm{DMSO}-\mathrm{d}_{6}\right) \delta_{\mathrm{C}} 172.1$ (5-C), 158.3 (1-C), 155.6 (10-C), 137.0 (12-C), 128.3 (14-C), 127.7 (15-C), 127.7 (13-C), 65.3 (11-C), 49.8 (6-C), 40.3 (2-C), 19.2 (7-C), 17.9 (3-C); $v_{\max } / \mathrm{cm}^{-1} 3287(\mathrm{~N}-\mathrm{H}), 3264(\mathrm{~N}-\mathrm{H}), 1684(\mathrm{C}=\mathrm{O}), 1655(\mathrm{C}=\mathrm{O}), 1535(\mathrm{~N}-\mathrm{H}), 1230(\mathrm{C}-\mathrm{O}) ; \mathrm{MS}(\mathrm{ESI})$ $m / z 319.2(\mathrm{M}+\mathrm{H})^{+}$; $\mathrm{CHN}$ [Found: $\mathrm{C}, 53.06 ; \mathrm{H}, 5.64 ; \mathrm{N}, 26.58 . \mathrm{C}_{14} \mathrm{H}_{18} \mathrm{~N}_{6} \mathrm{O}_{3}$ requires $\mathrm{C}, 52.82 ; \mathrm{H}, 5.70 ; \mathrm{N}$, $26.40 \%]$.

(2S)-2-amino-N-[(1S)-1-(1H-1,2,3,4-tetrazol-5-yl)ethyl]propanamide (14a-LL) [19]: Cbz-L-alanyl-1-Laminoethyltetrazole (13a-LL, $0.58 \mathrm{~g}, 1.83 \mathrm{mmol}$ ) was deprotected by general method E. Following filtration, the solid residue was washed with methanol, which was discarded. The solid residue was washed into a separate flask with water, then freeze dried to give the product as a white solid $(0.29 \mathrm{~g}$, $86 \%)$. Further purification was performed by Prep HPLC method A. The reaction and the work up were monitored by TLC (eluent: ethanol, $\left.\mathrm{R}_{\mathrm{f}}: 0.07\right)$. Mp: $200{ }^{\circ} \mathrm{C}$ (decomposed); ${ }^{1} \mathrm{H}-\mathrm{NMR}(300 \mathrm{MHz}$, $\left.\mathrm{D}_{2} \mathrm{O}\right) \delta_{\mathrm{H}} 5.25(1 \mathrm{H}$, quart, $J=6.9 \mathrm{~Hz}, 2-\mathrm{H}), 3.57(1 \mathrm{H}$, quart, $J=6.9 \mathrm{~Hz}, 6-\mathrm{H}), 1.52(3 \mathrm{H}, \mathrm{d}, J=7.2 \mathrm{~Hz}, 3-\mathrm{H})$, $1.25(3 \mathrm{H}, \mathrm{d}, J=7.2 \mathrm{~Hz}, 7-\mathrm{H}) ;{ }^{13} \mathrm{C}-\mathrm{NMR}\left(75.5 \mathrm{MHz}, \mathrm{D}_{2} \mathrm{O}\right) \delta_{\mathrm{C}} 176.2(5-\mathrm{C}), 164.3$ (1-C), 49.9 (6-C), 42.0 (2-C), $19.4(3-\mathrm{C}), 19.2$ (7-C); $v_{\max } / \mathrm{cm}^{-1} 3247(\mathrm{~N}-\mathrm{H}), 1643(\mathrm{C}=\mathrm{O}) 1561(\mathrm{~N}-\mathrm{H}) ; \mathrm{MS}(\mathrm{ESI}) \mathrm{m} / \mathrm{z} 185.1(\mathrm{M}+$ 
$\mathrm{H})^{+}$; HRMS (Found $(\mathrm{M}+\mathrm{H})^{+}$185.1145. Calcd. for $\mathrm{C}_{6} \mathrm{H}_{13} \mathrm{ON}_{6}:(\mathrm{M}+\mathrm{H})^{+}$185.1145.); (Purity test: HPLC method A).

Benzyl-N-[(1S)-1-\{[(1R)-1-(1H-1,2,3,4-tetrazol-5-yl)ethyl]carbamoyl\}ethyl]carbamate (13a-LD) [18]: Prepared using general method G. The Fmoc group of Fmoc-1-D-aminoethyltetrazole attached to 2-chlorotrityl chloride resin (resin:loading; 1:1 ratio; $1.2 \mathrm{mmol}$ ) was removed, this was monitored by the Fmoc and TNBS tests. After the coupling of Cbz-L-alanine with the resin, the title compound was cleaved off. The cleaving mixture (TFA/DCM/TIS, ratio 5:95:1 eq) was removed by evaporation under reduced pressure, and the residue washed with petroleum ether $\left(40-60{ }^{\circ} \mathrm{C}\right)$ to obtain the product as white crystals $(0.34 \mathrm{~g}, 89 \%)$. The reaction and the work up were monitored by TLC (eluent: ethyl acetate and 1 drop of glacial acetic acid, $\mathrm{R}_{\mathrm{f}}$ : 0.07). Mp: $166-168^{\circ} \mathrm{C} ;{ }^{1} \mathrm{H}-\mathrm{NMR}\left(300 \mathrm{MHz}, \mathrm{DMSO}-\mathrm{d}_{6}\right) \delta_{\mathrm{H}} 8.56(1 \mathrm{H}$, $\mathrm{d}, J=7.5 \mathrm{~Hz}, 4-\mathrm{H}), 7.35(6 \mathrm{H}, \mathrm{m}, 8,13-15-\mathrm{H}), 5.23(1 \mathrm{H}$, quint, $J=7.2 \mathrm{~Hz}, 2-\mathrm{H}), 5.04(1 \mathrm{H}, \mathrm{d}, J=12.9 \mathrm{~Hz}$, $\left.11-\mathrm{H}_{\mathrm{a}}\right), 5.00\left(1 \mathrm{H}, \mathrm{d}, J=12.6 \mathrm{~Hz}, 11-\mathrm{H}_{\mathrm{b}}\right), 4.10(1 \mathrm{H}$, quint, $J=7.5 \mathrm{~Hz}, 6-\mathrm{H}), 1.50(3 \mathrm{H}, \mathrm{d}, J=7.2 \mathrm{~Hz}, 3-\mathrm{H})$, $1.23(3 \mathrm{H}, \mathrm{d}, J=6.9 \mathrm{~Hz}, 7-\mathrm{H}){ }^{13} \mathrm{C}-\mathrm{NMR}\left(75.5 \mathrm{MHz}, \mathrm{DMSO}_{6} \mathrm{~d}_{6}\right) \delta_{\mathrm{C}} 172.6$ (5-C), $158.0(1-\mathrm{C}), 156.1(10-\mathrm{C})$, 137.4 (12-C), 128.8 (14-C), 128.2 (15-C), 128.2 (13-C), 65.9 (11-C), 50.4 (6-C), 40.3 (2-C), 19.6 (3-C), 18.8 (7-C); $v_{\max } / \mathrm{cm}^{-1} 3289(\mathrm{~N}-\mathrm{H}), 2988,2874,2756,2612$ (tetrazole), $1682(\mathrm{C}=\mathrm{O}), 1651(\mathrm{C}=\mathrm{O}), 1528(\mathrm{~N}-\mathrm{H})$, $1224(\mathrm{C}-\mathrm{O}) ; \mathrm{MS}(\mathrm{ESI}) \mathrm{m} / \mathrm{z} 319.1(\mathrm{M}+\mathrm{H})^{+}$; $\mathrm{CHN}$ [Found: $\mathrm{C}, 53.10 ; \mathrm{H}, 5.78 ; \mathrm{N}, 26.01 . \mathrm{C}_{14} \mathrm{H}_{18} \mathrm{~N}_{6} \mathrm{O}_{3}$ requires C, $52.82 ; \mathrm{H}, 5.70 ; \mathrm{N}, 26.40 \%]$.

(2S)-2-Amino-N-[(1R)-1-(1H-1,2,3,4-tetrazol-5-yl)ethyl]propanamide (14a-LD) [18]: Cbz-L-alanyl-1-Daminoethyltetrazole (13a-LD, $0.58 \mathrm{~g}, 1.83 \mathrm{mmol}$ ) was deprotected by general method E. Following filtration, the solid residue was washed with ethanol, which was discarded. The solid residue was washed into a separate flask with water, which was freeze dried and purified by column chromatography (eluent: ethyl acetate - ethanol 4:1, 2:1, 1:1 then 0:1 ratio) to give the pure product as white solid (98 mg, $58 \%$ ). The reaction and the work up were monitored by TLC (eluent: ethanol, $\left.\mathrm{R}_{\mathrm{f}}: 0.13\right)$. Mp: $69^{\circ} \mathrm{C}$ (phase change), $177^{\circ} \mathrm{C}$ (melted); ${ }^{1} \mathrm{H}-\mathrm{NMR}\left(300 \mathrm{MHz}, \mathrm{D}_{2} \mathrm{O}\right) \delta_{\mathrm{H}} 5.24\left({ }^{1} \mathrm{H}\right.$, quart, $\left.J=6.6 \mathrm{~Hz}, 2-\mathrm{H}\right), 4.00$ $(1 \mathrm{H}$, quart, $J=6.6 \mathrm{~Hz}, 6-\mathrm{H}), 1.52(3 \mathrm{H}, \mathrm{d}, J=7.5 \mathrm{~Hz}, 3-\mathrm{H}), 1.48(3 \mathrm{H}, \mathrm{d}, J=7.8 \mathrm{~Hz}, 7-\mathrm{H}) ;{ }^{13} \mathrm{C}-\mathrm{NMR}$ (75.5 MHz, $\mathrm{D}_{2} \mathrm{O}$ ) $\delta_{\mathrm{C}} 170.5(5-\mathrm{C}), 164.0(1-\mathrm{C}), 49.3(6-\mathrm{C}), 42.3(2-\mathrm{C}), 19.1(3-\mathrm{C}), 16.7(7-\mathrm{C}) ; v_{\max } / \mathrm{cm}^{-1} 3204$ $(\mathrm{N}-\mathrm{H}), 1667(\mathrm{C}=\mathrm{O}), 1539(\mathrm{~N}-\mathrm{H})$; MS(ESI) $m / z 185.1(\mathrm{M}+\mathrm{H})^{+}$; HRMS (Found $(\mathrm{M}+\mathrm{H})^{+}$185.1145. Calcd. for $\mathrm{C}_{6} \mathrm{H}_{13} \mathrm{ON}_{6}$ : $(\mathrm{M}+\mathrm{H})^{+}$185.1145.); (Purity test: HPLC method A).

(S)-Benzyl-(3-((1-(1H-tetrazol-5-yl)ethyl)amino)-3-oxopropyl)carbamate (13d-L): Prepared using general method G. The Fmoc group of Fmoc-1-L-aminoethyltetrazole attached to the 2-chlorotrityl chloride resin (resin:loading; 1:1 ratio; $1.3 \mathrm{mmol}$ ) was removed, this was monitored by the Fmoc and TNBS tests. After the coupling of Cbz- $\beta$-alanine with the resin, the title compound was cleaved off. The cleaving mixture (TFA/DCM/TIS, ratio 5:95:1 eq) was removed by evaporation under reduced pressure, and the residue washed with petroleum ether $\left(40-60^{\circ} \mathrm{C}\right)$ to obtained the product as white crystals $(0.28 \mathrm{~g}, 67 \%)$. The reaction and the work up were monitored by TLC (eluent: ethyl acetate and 1 drop of glacial acetic acid, $\left.\mathrm{R}_{\mathrm{f}}: 0.39\right)$. Mp: $147-148^{\circ} \mathrm{C} ;{ }^{1} \mathrm{H}-\mathrm{NMR}\left(300 \mathrm{MHz}, \mathrm{DMSO}-\mathrm{d}_{6}\right) \delta_{\mathrm{H}} 16.08(1 \mathrm{H}, \mathrm{brs}, 9-\mathrm{H})$, $8.56(1 \mathrm{H}, \mathrm{d}, J=7.5 \mathrm{~Hz}, 4-\mathrm{H}), 7.35(5 \mathrm{H}, \mathrm{m}, 13-15-\mathrm{H}), 7.21(1 \mathrm{H}, \mathrm{m}, 8-\mathrm{H}), 5.22(1 \mathrm{H}$, quint, $J=7.2 \mathrm{~Hz}, 2-\mathrm{H})$, $5.02(2 \mathrm{H}, \mathrm{s}, 11-\mathrm{H}), 3.24(2 \mathrm{H}$, quart, $J=6.9 \mathrm{~Hz}, 7-\mathrm{H}), 2.34(2 \mathrm{H}, \mathrm{t}, J=6.9 \mathrm{~Hz}, 6-\mathrm{H}), 1.48(3 \mathrm{H}, \mathrm{d}, J=7.2 \mathrm{~Hz}$, 3-H) ${ }^{13} \mathrm{C}-\mathrm{NMR}\left(75,5 \mathrm{MHz}, \mathrm{DMSO}-\mathrm{d}_{6}\right) \delta_{\mathrm{C}} 170.6$ (5-C), 158.8 (1-C), 156.5 (10-C), 137.6 (12-C), 128.8 (2C, 14-C), 128.2 (15-C), 128.1 (2C, 13-C), 65.7 (11-C), 40.9 (2-C), $37.3(7-C), 35.9(6-C), 19.6(3-C) ; v_{\max } / \mathrm{cm}^{-1}$ $3323(\mathrm{~N}-\mathrm{H}), 3273(\mathrm{~N}-\mathrm{H}), 2994,2882,2746,2615$ (tetrazole), $1692(\mathrm{C}=\mathrm{O}), 1645(\mathrm{C}=\mathrm{O})$; MS(ESI) $(\mathrm{M}+\mathrm{Na})^{+}$ found $341.2 \mathrm{~m} / z$; HRMS (Found $(\mathrm{M}+\mathrm{H})^{+}$319.1516. Calcd. for $\mathrm{C}_{14} \mathrm{H}_{19} \mathrm{O}_{3} \mathrm{~N}_{6}:(\mathrm{M}+\mathrm{H})^{+}$319.1513.); (Purity test: HPLC method C).

3-Amino-N-[(1S)-1-(1H-1,2,3,4-tetrazol-5-yl)ethyl]propanamide $\quad(\mathbf{1 4 d - L})$ : Cbz- $\beta$-alanyl-1-L-aminoethyltetrazole (13d-L, $0.20 \mathrm{~g}, 0.63 \mathrm{mmol}$ ) was deprotected by general method E. Following filtration, the solid residue was washed with methanol, which was discarded. The solid residue was washed into a separate flask with water, which was freeze dried to give the product as a light brown hygroscopic amorphous solid $\left(0.09 \mathrm{~g}\right.$, 78\%). Further purification was performed by Prep HPLC method A. ${ }^{1} \mathrm{H}-\mathrm{NMR}$ 
$\left(300 \mathrm{MHz}, \mathrm{D}_{2} \mathrm{O}\right) \delta_{\mathrm{H}} 5.21(1 \mathrm{H}$, quart, $J=6.9 \mathrm{~Hz}, 2-\mathrm{H}), 3.17(2 \mathrm{H}, \mathrm{m}, 7-\mathrm{H}), 2.63(2 \mathrm{H}, \mathrm{t}, J=6.6 \mathrm{~Hz}, 6-\mathrm{H}), 1.48$ $(3 \mathrm{H}, \mathrm{d}, J=6.9 \mathrm{~Hz}, 3-\mathrm{H}) ;{ }^{13} \mathrm{C}-\mathrm{NMR}\left(75,5 \mathrm{MHz}, \mathrm{DMSO}-\mathrm{d}_{6}\right) \delta_{\mathrm{C}} 171.6$ (5-C), 164.5 (1-C), 40.0 (2-C), 35.8 (7-C), $32.5(6-\mathrm{C}), 19.3(3-\mathrm{C}) ; v_{\max } / \mathrm{cm}^{-1} 3232(\mathrm{~N}-\mathrm{H}), 1641(\mathrm{C}=\mathrm{O}) ; \mathrm{MS}(\mathrm{ESI})(\mathrm{M}+\mathrm{H})^{+}$found $185.1 \mathrm{~m} / \mathrm{z}$; HRMS (Found $(\mathrm{M}+\mathrm{H})^{+}$185.1145. Calcd. for $\mathrm{C}_{6} \mathrm{H}_{13} \mathrm{ON}_{6}$ : $(\mathrm{M}+\mathrm{H})^{+}$185.1145.); (Purity test: HPLC method A).

Benzyl-N-[(1S)-1-\{[(1S)-1-(1H-1,2,3,4-tetrazol-5-yl)ethyl]carbamoyl\}butyl]carbamate (13e-LL): Prepared using general method G. The Fmoc group of Fmoc-1-L-aminoethyltetrazole attached to 2-chlorotrityl chloride resin (resin:loading; 1:1 ratio; $1.2 \mathrm{mmol}$ ) was removed, this was monitored by the Fmoc and TNBS tests. After the coupling of Cbz-L-norvaline with the resin, the title compound was cleaved off. The cleaving mixture (TFA/DCM/TIS, ratio 5:95:1 eq) was removed by evaporation under reduced pressure, and the residue washed with petroleum ether $\left(40-60{ }^{\circ} \mathrm{C}\right)$ to obtain the product as white crystals $(0.21,51 \%)$. The reaction and the work up were monitored by TLC (eluent: ethyl acetate and 1 drop of glacial acetic acid, $\mathrm{R}_{\mathrm{f}}$ : 0.2). Mp: $175-178^{\circ} \mathrm{C} ;{ }^{1} \mathrm{H}-\mathrm{NMR}\left(300 \mathrm{MHz}, \mathrm{DMSO}-\mathrm{d}_{6}\right) \delta_{\mathrm{H}} 16.22(1 \mathrm{H}$, brs, 11-H), $8.55(1 \mathrm{H}, \mathrm{d}, J=7.5,4-\mathrm{H}), 7.35(6 \mathrm{H}, \mathrm{m}, 10,15-17-\mathrm{H}), 5.23(1 \mathrm{H}$, quint, $J=7.2 \mathrm{~Hz}, 2-\mathrm{H}), 5.02(2 \mathrm{H}, \mathrm{s}$, 13-H), $4.04(1 \mathrm{H}, \mathrm{m}, 6-\mathrm{H}), 1.59(2 \mathrm{H}, \mathrm{m}, 7-\mathrm{H}), 1.49(3 \mathrm{H}, \mathrm{d}, J=6.9 \mathrm{~Hz}, 3-\mathrm{H}), 1.27(2 \mathrm{H}, \mathrm{m}, 8-\mathrm{H}), 0.84(3 \mathrm{H}, \mathrm{t}$, $J=7.2 \mathrm{~Hz}, 9-\mathrm{H}) ;{ }^{13} \mathrm{C}-\mathrm{NMR}\left(75.5 \mathrm{MHz}, \mathrm{DMSO}-\mathrm{d}_{6}\right) \delta_{\mathrm{C}} 172.2$ (5-C), 159.1 (1-C), 156.4 (12-C), 137.5 (14-C), 128.8 (2C, 16-C), 128.2 (17-C), 128.1 (2C, 15-C), 65.8 (13-C), 54.6 (6-C), 40.9 (2-C), 34.3 (7-C), 19.7 (3-C), $19.1(8-\mathrm{C}), 14.0(9-\mathrm{C}) ; v_{\max } / \mathrm{cm}^{-1} 3310(\mathrm{~N}-\mathrm{H}), 3271(\mathrm{~N}-\mathrm{H}), 2959,2877,2752,2609$ (tetrazole), $1682(\mathrm{C}=\mathrm{O})$, $1651(\mathrm{C}=\mathrm{O}), 1533(\mathrm{~N}-\mathrm{H}), 1234(\mathrm{C}-\mathrm{O})$; MS(ESI) $\mathrm{m} / \mathrm{z} 369.2(\mathrm{M}+\mathrm{Na})^{+}$; HRMS (Found $(\mathrm{M}+\mathrm{H})^{+} 347.1830$. Calcd. for $\mathrm{C}_{16} \mathrm{H}_{23} \mathrm{O}_{3} \mathrm{~N}_{6}:(\mathrm{M}+\mathrm{H})^{+}$347.1826.); (Purity test: HPLC method D)

(S)-N-((S)-1-(1H-tetrazol-5-yl)ethyl)-2-aminopentanamide (14e-LL): Cbz-L-norvalyl-1-L-amino-ethyltetrazole (13e-LL, $0.10 \mathrm{~g}, 0.29 \mathrm{mmol}$ ) was deprotected by general method E. Following filtration, the solid residue was washed with methanol, which was discarded. The residue was washed with water, then freeze dried to give the product as a white solid ( $47 \mathrm{mg}, 77 \%)$. Further purification was performed by Prep HPLC method A. The reaction and the work up were monitored by TLC (eluent: ethanol, $\left.\mathrm{R}_{\mathrm{f}}: 0.16\right)$. Mp: 251-254 ${ }^{\circ} \mathrm{C} ;{ }^{1} \mathrm{H}-\mathrm{NMR}\left(300 \mathrm{MHz}, \mathrm{D}_{2} \mathrm{O}\right) \delta_{\mathrm{H}} 5.28(1 \mathrm{H}$, quart, $J=7.2 \mathrm{~Hz}, 2-\mathrm{H}), 3.79(1 \mathrm{H}, \mathrm{t}, J=6.6 \mathrm{~Hz}, 6-\mathrm{H}), 1.70(2 \mathrm{H}, \mathrm{m}$, 7-H), $1.54(3 \mathrm{H}, \mathrm{d}, J=6.9 \mathrm{~Hz}, 3-\mathrm{H}), 1.21(2 \mathrm{H}, \mathrm{m}, 8-\mathrm{H}), 0.81(3 \mathrm{H}, \mathrm{t}, J=7.2 \mathrm{~Hz}, 9-\mathrm{H}) ;{ }^{13} \mathrm{C}-\mathrm{NMR}(75.5 \mathrm{MHz}$, DMSO-d $\left._{6}\right) \delta_{C} 171.2(5-\mathrm{C}), 164.7(1-\mathrm{C}), 53.5(6-\mathrm{C}), 42.0(2-\mathrm{C}), 33.8$ (7-C), 19.1 (3-C), $17.6(8-\mathrm{C}), 12.8$ (9-C); $v_{\max } / \mathrm{cm}^{-1} 3210(\mathrm{~N}-\mathrm{H}), 1687(\mathrm{C}=\mathrm{O}), 1551(\mathrm{~N}-\mathrm{H}) ; \mathrm{MS}(\mathrm{ESI}) \mathrm{m} / \mathrm{z} 213.1(\mathrm{M}+\mathrm{H})^{+}$; HRMS (Found $(\mathrm{M}+\mathrm{H})^{+}$ 213.1458. Calcd. for $\mathrm{C}_{8} \mathrm{H}_{17} \mathrm{ON}_{6}:(\mathrm{M}+\mathrm{H})^{+}$213.1460.); (Purity test: HPLC method A).

Benzyl-N-[(1S)-3-methyl-1-\{[(1S)-1-(1H-1,2,3,4-tetrazol-5-yl)ethyl]carbamoyl\}butyl]carbamate (13h-LL): Prepared using general method G. The Fmoc group of Fmoc-1-L-aminoethyltetrazole attached to 2-chlorotrityl chloride resin (resin:loading; 1:2 ratio; $1.5 \mathrm{mmol}$ ) was removed, this was monitored by the Fmoc and TNBS tests. After the coupling of Cbz-L-leucine with the resin, the title compound was cleaved off. The cleaving mixture (TFA/DCM/TIS, ratio 5:95:1 eq) was removed by evaporation under reduced pressure, and the residue washed with petroleum ether $\left(40-60^{\circ} \mathrm{C}\right)$ to obtain the product as white crystals $(0.45,84 \%)$. The reaction and the work up were monitored by TLC (eluent: ethyl acetate ethanol - drop of glacial acetic acid 1:1 ratio, $\left.\mathrm{R}_{\mathrm{f}}: 0.64\right)$. Mp: $149-150{ }^{\circ} \mathrm{C} ;{ }^{1} \mathrm{H}-\mathrm{NMR}\left(300 \mathrm{MHz}, \mathrm{DMSO}-\mathrm{d}_{6}\right)$ $\delta_{\mathrm{H}} 16.1(1 \mathrm{H}, \mathrm{brs}, 11-\mathrm{H}), 8.55(1 \mathrm{H}, \mathrm{d}, J=7.5 \mathrm{~Hz}, 4-\mathrm{H}), 7.36(6 \mathrm{H}, \mathrm{m}, 10,15,16,17-\mathrm{H}), 5.22(1 \mathrm{H}$, quint, $J$ $=6.9 \mathrm{~Hz}, 2-\mathrm{H}), 5.04(1 \mathrm{H}, \mathrm{d}, J=12.6,13 \mathrm{a}-\mathrm{H}), 5.00(1 \mathrm{H}, \mathrm{d}, J=12.6 \mathrm{~Hz}, 13 \mathrm{a}-\mathrm{H}), 4.07(1 \mathrm{H}, \mathrm{m}, 6-\mathrm{H}), 1.60$ $(1 \mathrm{H}, \mathrm{m}, 8-\mathrm{H}), 1.49(3 \mathrm{H}, \mathrm{d}, J=7.2 \mathrm{~Hz}, 3-\mathrm{H}), 1.42(2 \mathrm{H}, \mathrm{m}, 7-\mathrm{H}), 0.85(3 \mathrm{H}, \mathrm{d}, J=6.6 \mathrm{~Hz}, 9 \mathrm{a}-\mathrm{H}), 0.84(3 \mathrm{H}$, $\mathrm{d}, J=6.6 \mathrm{~Hz}, 9 \mathrm{~b}-\mathrm{H}) ;{ }^{13} \mathrm{C}-\mathrm{NMR}\left(75.5 \mathrm{MHz}, \mathrm{DMSO}_{-} \mathrm{d}_{6}\right) \delta_{\mathrm{C}} 172.6$ (5-C), 156.4 (12-C), 137.5 (14-C), 128.8 (16-C), 128.2 (17-C), 128.1 (15-C), 65.8 (13-C), 53.3 (6-C), 41.0 (2-C), 40.3 (7-C), 24.6 (8-C), 23.6 (9a-C), 21.8 (9b-C), $19.6(3-\mathrm{C}) ; v_{\max } / \mathrm{cm}^{-1} 3316(\mathrm{~N}-\mathrm{H}), 3271(\mathrm{~N}-\mathrm{H}), 2961,2876,2743,2615$ (tetrazole), $1682(\mathrm{C}=\mathrm{O})$, $1653(\mathrm{C}=\mathrm{O}), 1530(\mathrm{~N}-\mathrm{H}), 1233(\mathrm{C}-\mathrm{O})$; MS(ESI) $\mathrm{m} / \mathrm{z} 360.8(\mathrm{M}+\mathrm{H})^{+}$; CHN [Found: C, 56.82.; H, 6.68; N, 23.05. $\mathrm{C}_{17} \mathrm{H}_{24} \mathrm{~N}_{6} \mathrm{O}_{3}$ requires $\left.\mathrm{C}, 56.65 ; \mathrm{H}, 6.71 ; \mathrm{N}, 23.32 \%\right]$.

(2S)-2-Amino-4-methyl-N-[(1S)-1-(1H-1,2,3,4-tetrazol-5-yl)ethyl]pentanamide (14h-LL): Cbz-L-leucyl-1-Laminoethyltetrazole (13h-LL, $0.95 \mathrm{~g}, 2.6 \mathrm{mmol})$ was deprotected by general method E. Following 
filtration, the solid residue was washed with ethanol, which was discarded. The residue was washed with water, then freeze dried and washed with diethyl ether to give the product as a white solid ( $0.48 \mathrm{~g}$, $81 \%$ ). Further purification was performed by Prep HPLC method A. The reaction and the work up were monitored by TLC (eluent: ethanol, $\mathrm{R}_{\mathrm{f}}$ : 0.3). Mp: $210{ }^{\circ} \mathrm{C}$ (decomposed); ${ }^{1} \mathrm{H}-\mathrm{NMR}\left(300 \mathrm{MHz}, \mathrm{D}_{2} \mathrm{O}\right)$ $\delta_{\mathrm{H}} 5.28(1 \mathrm{H}$, quart, $J=7.2 \mathrm{~Hz}, 2-\mathrm{H}), 3.49(1 \mathrm{H}, \mathrm{t}, J=7.2 \mathrm{~Hz}, 6-\mathrm{H}), 1.53(3 \mathrm{H}, \mathrm{d}, J=7.2 \mathrm{~Hz}, 3-\mathrm{H}), 1.44(3 \mathrm{H}$, $\mathrm{m}, 7,8-\mathrm{H}), 0.82(3 \mathrm{H}, \mathrm{d}, J=4.8 \mathrm{~Hz}, 9 \mathrm{a}-\mathrm{H}), 0.80(3 \mathrm{H}, \mathrm{d}, J=5.1 \mathrm{~Hz}, 9 \mathrm{~b}-\mathrm{H}) ;{ }^{13} \mathrm{C}-\mathrm{NMR}\left(75.5 \mathrm{MHz}, \mathrm{DMSO}^{\left.-\mathrm{d}_{6}\right)}\right.$ $\delta_{C} 175.6(5-C), 169.7$ (1-C), 52.9 (6-C), 42.7 (7-C), 41.8 (2-C), 24.0 (8-C), 21.9 (9a-C), 21.4 (9b-C), 16.8 (3-C); $v_{\max } / \mathrm{cm}^{-1} 3219(\mathrm{~N}-\mathrm{H}), 1653(\mathrm{C}=\mathrm{O}), 1562(\mathrm{~N}-\mathrm{H}) ; \mathrm{MS}(\mathrm{ESI}) \mathrm{m} / z 227.2(\mathrm{M}+\mathrm{H})^{+} ;$HRMS $\left(\right.$Found $(\mathrm{M}+\mathrm{Na})^{+}$ 249.1436. Calcd. for $\mathrm{C}_{9} \mathrm{H}_{18} \mathrm{ON}_{6} \mathrm{Na}$ : $(\mathrm{M}+\mathrm{Na})^{+}$249.1434.); (Purity test: HPLC method A).

Benzyl-N-[(1S)-3-methyl-1-\{[(1R)-1-(1H-1,2,3,4-tetrazol-5-yl)ethyl]carbamoyl\}butyl]carbamate (13h-LD): Prepared using general method G. The Fmoc group of Fmoc-1-D-aminoethyltetrazole attached to 2-chlorotrityl chloride resin (resin:loading; 1:1 ratio; $1.2 \mathrm{mmol}$ ) was removed, this was monitored by Fmoc and TNBS tests. After the coupling of Cbz-L-leucine with the resin, the title compound was cleaved off. The cleaving mixture (TFA/DCM/TIS, ratio 5:95:1 eq) was removed by evaporation under reduced pressure, and washed with petroleum ether $\left(40-60^{\circ} \mathrm{C}\right)$ to obtain the product as white crystals $(0.30 \mathrm{~g}, 69 \%)$. The reaction and the work up were monitored by TLC (eluent: ethyl acetate - ethanol 1:1 ratio, $\mathrm{R}_{\mathrm{f}}$ : 0.63). Mp: $143-144{ }^{\circ} \mathrm{C} ;{ }^{1} \mathrm{H}-\mathrm{NMR}\left(300 \mathrm{MHz}, \mathrm{DMSO}-\mathrm{d}_{6}\right) \delta_{\mathrm{H}} 16.2(1 \mathrm{H}, \mathrm{brs}, 11-\mathrm{H}), 8.61(1 \mathrm{H}$, $\mathrm{d}, J=7.5 \mathrm{~Hz}, 4-\mathrm{H}), 7.35(6 \mathrm{H}, \mathrm{m}, 10,15,16,17-\mathrm{H}), 5.26(1 \mathrm{H}$, quint, $J=7.5 \mathrm{~Hz}, 2-\mathrm{H}), 5.04(1 \mathrm{H}, \mathrm{d}, J=13.2$, 13a-H), $5.00(1 \mathrm{H}, \mathrm{d}, J=12.9 \mathrm{~Hz}, 13 \mathrm{a}-\mathrm{H}), 4.11(1 \mathrm{H}, \mathrm{m}, 6-\mathrm{H}), 1.61(1 \mathrm{H}, \mathrm{m}, 8-\mathrm{H}), 1.45(3 \mathrm{H}, \mathrm{d}, J=6.9 \mathrm{~Hz}, 3-\mathrm{H})$, $1.42(2 \mathrm{H}, \mathrm{m}, 7-\mathrm{H}), 0.88(3 \mathrm{H}, \mathrm{d}, J=6.0 \mathrm{~Hz}, 9 \mathrm{a}-\mathrm{H}), 0.86(3 \mathrm{H}, \mathrm{d}, J=5.7 \mathrm{~Hz}, 9 \mathrm{~b}-\mathrm{H}) ;{ }^{13} \mathrm{C}-\mathrm{NMR}(75.5 \mathrm{MHz}$, DMSO-d $\left._{6}\right) \delta_{\mathrm{C}} 172.4(5-\mathrm{C}), 158.5(1-\mathrm{C}), 156.4(12-\mathrm{C}), 137.5$ (14-C), 128.8 (16-C), 128.2 (17-C), 128.1 (15-C), 65.9 (13-C), 53.4 (6-C), 41.4 (2-C), 40.3 (7-C), 24.7 (8-C), 23.5 (9a-C), 21.9 (9b-C), $19.6(3-C) ; v_{\max } / \mathrm{cm}^{-1}$ $3312(\mathrm{~N}-\mathrm{H}), 3269(\mathrm{~N}-\mathrm{H})$, 2959, 2876, 2756, 2621 (tetrazole) $1690(\mathrm{C}=\mathrm{O}), 1649(\mathrm{C}=), 1528(\mathrm{~N}-\mathrm{H}), 1234$ (C-O); MS(ESI) $m / z$ 361.2 (M + H); HRMS (Found $(\mathrm{M}+\mathrm{H})^{+}$361.1987. Calcd. for $\mathrm{C}_{17} \mathrm{H}_{25} \mathrm{O}_{3} \mathrm{~N}_{6}:(\mathrm{M}+$ $\mathrm{H})^{+}$361.1983.); (Purity test: HPLC method D).

(2S)-2-Amino-4-methyl-N-[(1R)-1-(1H-1,2,3,4-tetrazol-5-yl)ethyl]pentanamide (14h-LD): Cbz-L-leucyl-1-Daminoethyltetrazole (13h-LD, $0.25 \mathrm{~g}, 0.7 \mathrm{mmol})$ was deprotected by general method E. Following filtration, the solid residue was washed with ethanol, which was discarded. The residue was washed with water, which was freeze dried and purified by column chromatography (eluent: ethyl acetate ethanol 1:1-1:2-0:1) to give the pure product as a white solid ( $83 \mathrm{mg}, 53 \%)$. The reaction and the work up were monitored by TLC (eluent: ethanol, $\mathrm{R}_{\mathrm{f}}$ : 0.21). Mp: $136{ }^{\circ} \mathrm{C}$ (decomposed), $161{ }^{\circ} \mathrm{C}$ (melted); ${ }^{1} \mathrm{H}-\mathrm{NMR}\left(300 \mathrm{MHz}, \mathrm{D}_{2} \mathrm{O}\right) \delta_{\mathrm{H}} 5.27(1 \mathrm{H}$, quart, $J=6.9 \mathrm{~Hz}, 2-\mathrm{H}), 3.95(1 \mathrm{H}, \mathrm{t}, J=6.9 \mathrm{~Hz}, 6-\mathrm{H}), 1.71(3 \mathrm{H}$, m, 7,8-H), $1.53(3 \mathrm{H}, \mathrm{d}, J=7.2 \mathrm{~Hz}, 3-\mathrm{H}), 0.93(3 \mathrm{H}, \mathrm{d}, J=6.0 \mathrm{~Hz}, 9 \mathrm{a}-\mathrm{H}), 0.91(3 \mathrm{H}, \mathrm{d}, J=6.0 \mathrm{~Hz}, 9 \mathrm{~b}-\mathrm{H})$; ${ }^{13}$ C-NMR (75.5 MHz, DMSO-d 6 ) $\delta_{C} 169.8$ (5-C), 164.7 (1-C), 52.2 (6-C), $42.4(2-\mathrm{C}), 39.9$ (7-C), 24.0 (8-C), 21.6 (9a-C), 21.3 (9b-C), 19.1 (3-C); $v_{\max } / \mathrm{cm}^{-1} 3194$ (N-H), 1667 (C=O), 1543 (N-H); MS(ESI) m/z 227.2 $(\mathrm{M}+\mathrm{H})^{+}$; HRMS (Found $(\mathrm{M}+\mathrm{H})^{+} 227.1625$ Calcd. for $\mathrm{C}_{9} \mathrm{H}_{19} \mathrm{ON}_{6}:(\mathrm{M}+\mathrm{H})^{+}$227.1620.); (Purity test: HPLC method A).

Benzyl-N-[(1S,2S)-2-methyl-1-\{[(1S)-1-(1H-1,2,3,4-tetrazol-5-yl)ethyl]carbamoyl\}butyl]carbamate (13i-LL): Prepared using general method G. The Fmoc group of Fmoc-1-L-aminoethyltetrazole attached to 2-chlorotrityl chloride resin (resin:loading; 1:1 ratio; $1.8 \mathrm{mmol}$ ) was removed, this was monitored by the Fmoc and TNBS tests. After the coupling of Cbz-L-isoleucine with the resin, the title compound was cleaved off. The cleaving mixture (TFA/DCM/TIS, ratio 5:95:1 eq) was removed by evaporation under reduced pressure, and washed with petroleum ether $\left(40-60{ }^{\circ} \mathrm{C}\right)$ to obtain the product as white crystals $(0.40 \mathrm{~g}, 62 \%)$. The reaction and the work up were monitored by TLC (eluent: ethyl acetate ethanol 10:1 ratio, $\mathrm{R}_{\mathrm{f}}$ : 0.13). Mp: $186-189{ }^{\circ} \mathrm{C} ;{ }^{1} \mathrm{H}-\mathrm{NMR}\left(300 \mathrm{MHz}, \mathrm{DMSO}-\mathrm{d}_{6}\right) \delta_{\mathrm{H}} 8.58(1 \mathrm{H}, \mathrm{d}, J=7.2 \mathrm{~Hz}$, 4-H), $7.35(5 \mathrm{H}, \mathrm{m}, 16,17,18-\mathrm{H}), 7.24(1 \mathrm{H}, \mathrm{d}, J=9.0 \mathrm{~Hz}, 11-\mathrm{H}), 5.24(1 \mathrm{H}$, quint, $J=6.9 \mathrm{~Hz}, 2-\mathrm{H}), 5.05(1 \mathrm{H}$, $\mathrm{d}, J=12.6 \mathrm{~Hz}, 14 \mathrm{a}-\mathrm{H}), 5.00(1 \mathrm{H}, \mathrm{d}, J=12.6 \mathrm{~Hz}, 14 \mathrm{~b}-\mathrm{H}), 3.92(1 \mathrm{H}, \mathrm{t}, J=8.1 \mathrm{~Hz}, 6-\mathrm{H}), 1.70(1 \mathrm{H}, \mathrm{m}, 7-\mathrm{H})$, $1.50(3 \mathrm{H}, \mathrm{d}, J=6.9 \mathrm{~Hz}, 3-\mathrm{H}), 1.35(1 \mathrm{H}, \mathrm{m}, 9 \mathrm{a}-\mathrm{H}), 1.07(1 \mathrm{H}, \mathrm{m}, 9 \mathrm{~b}-\mathrm{H}), 0.77(3 \mathrm{H}, \mathrm{t}, J=7.5 \mathrm{~Hz}, 10-\mathrm{H}), 0.75$ $(3 \mathrm{H}, \mathrm{d}, J=7.5 \mathrm{~Hz}, 8-\mathrm{H}) ;{ }^{13} \mathrm{C}-\mathrm{NMR}\left(75.5 \mathrm{MHz}, \mathrm{DMSO}-\mathrm{d}_{6}\right) \delta_{\mathrm{C}} 171.4$ (5-C), 158.3 (1-C), 156.5 (13-C), 137.5 
(15-C), 128.8 (17-C), 128.2 (18-C), 128.1 (16-C), 65.9 (14-C), 59.3 (6-C), 39.9 (2-C), 36.9 (7-C), 24.7 (9-C), $19.5(3-\mathrm{C}), 15.7(8-\mathrm{C}), 11.3(10-\mathrm{C}) ; v_{\max } / \mathrm{cm}^{-1} 3279(\mathrm{~N}-\mathrm{H}), 2963,2878,2693,2608$ (tetrazole), $1690(\mathrm{C}=\mathrm{O})$, 1651 (C=O), $1535(\mathrm{~N}-\mathrm{H}), 1234(\mathrm{C}-\mathrm{O})$; MS(ESI) $\mathrm{m} / \mathrm{z} 361.1(\mathrm{M}+\mathrm{H})^{+}$; CHN [Found: C, 56.61.; H, 6.77; N, 23.01. $\mathrm{C}_{17} \mathrm{H}_{24} \mathrm{~N}_{6} \mathrm{O}_{3}$ requires $\left.\mathrm{C}, 56.65 ; \mathrm{H}, 6.71 ; \mathrm{N}, 23.32 \%\right]$.

(2S,3S)-2-amino-3-methyl-N-[(1S)-1-(1H-1,2,3,4-tetrazol-5-yl)ethyl]pentanamide (14i-LL): Cbz-L-isoleucyl1-L-aminoethyltetrazole (13i-LL, $0.35 \mathrm{~g}, 0.9 \mathrm{mmol}$ ) was deprotected by general method E. Following filtration, the solid residue was washed with ethanol, which was discarded. The residue was washed with water, which was freeze dried to give the product as white solid (190 mg, 86\%). Due to hygroscopicity, the corresponding hydrochloride salt was made with $2 \mathrm{M} \mathrm{HCl}$ in diethyl ether solution $(20 \mathrm{~mL})$ for characterization. Further purification was performed by Prep HPLC method A. The reaction and the work up were monitored by TLC (eluent: ethanol, $\mathrm{R}_{\mathrm{f}}: 0.31$ ). Mp: $164-167^{\circ} \mathrm{C}$ (melted and decomposed); ${ }^{1} \mathrm{H}-\mathrm{NMR}\left(300 \mathrm{MHz}, \mathrm{D}_{2} \mathrm{O}\right) \delta_{\mathrm{H}} 5.39(1 \mathrm{H}$, quart, $J=7.2 \mathrm{~Hz}, 2-\mathrm{H}), 3.85(1 \mathrm{H}, \mathrm{d}, J=5.7 \mathrm{~Hz}$, 6-H), $1.92(1 \mathrm{H}, \mathrm{m}, 7-\mathrm{H}), 1.65(3 \mathrm{H}, \mathrm{d}, J=7.2 \mathrm{~Hz}, 3-\mathrm{H}), 1.31(1 \mathrm{H}, \mathrm{m}, 9 \mathrm{a}-\mathrm{H}), 1.14(1 \mathrm{H}, \mathrm{m}, 9 \mathrm{~b}-\mathrm{H}), 0.89$ (3H, d, $J=6.9 \mathrm{~Hz}, 8-\mathrm{H}), 0.83(3 \mathrm{H}, \mathrm{t}, J=7.5 \mathrm{~Hz}, 10-\mathrm{H}) ;{ }^{13} \mathrm{C}-\mathrm{NMR}\left(75.5 \mathrm{MHz}, \mathrm{DMSO}-\mathrm{d}_{6}\right) \delta_{\mathrm{C}} 169.1(5-\mathrm{C}), 158.1$ (1-C), 57.7 (6-C), 40.7 (2-C), 36.3 (7-C), 23.9 (9-C), 17.6 (3-C), 14.1 (8-C), 10.4 (10-C); $v_{\max } / \mathrm{cm}^{-1} 3240$ $(\mathrm{N}-\mathrm{H}), 1682(\mathrm{C}=\mathrm{O}), 1574(\mathrm{~N}-\mathrm{H})$; MS(ESI) $m / z 227.2(\mathrm{M}+\mathrm{H})^{+}$; HRMS (Found $(\mathrm{M}+\mathrm{Na})^{+}$249.1436. Calcd. for $\mathrm{C}_{9} \mathrm{H}_{18} \mathrm{ON}_{6} \mathrm{Na}$ : $(\mathrm{M}+\mathrm{Na})^{+}$249.1434.); (Purity test: HPLC method A).

Benzyl-(5S)-2-oxo-5-\{[(1S)-1-(1H-1,2,3,4-tetrazol-5-yl)ethyl]carbamoyl\}pyrrolidine-1-carboxylate (13f-LL): Prepared using general method G. The Fmoc group of the Fmoc-1-L-aminoethyltetrazole attached to 2-chlorotrityl chloride resin (resin:loading; 1:2 ratio; $2.0 \mathrm{mmol}$ ) was removed. After coupling of Cbz-L-pyroglutamine with the resin, the title compound was cleaved off. The cleaving mixture (TFA/DCM/TIS, ratio 5:95:1 eq) was subsequently removed by evaporation under reduced pressure. The crude product was purified by column chromatography (eluent: ethyl acetate - ethanol 10:1, 6:1 then $1: 1$ ratio) to obtain the product as white crystals $(0.46 \mathrm{~g}, 65 \%)$. The reaction and the work up were monitored by TLC (eluent: ethyl acetate - ethanol 10:1, $\mathrm{R}_{\mathrm{f}}: 0.09$ ). Mp: $195{ }^{\circ} \mathrm{C}$ (decomposed); ${ }^{1} \mathrm{H}-\mathrm{NMR}$ $\left(300 \mathrm{MHz}, \mathrm{DMSO}_{6}\right) \delta_{\mathrm{H}} 16.05(1 \mathrm{H}, \mathrm{brs}, 11-\mathrm{H}), 8.93(1 \mathrm{H}, \mathrm{d}, J=7.5 \mathrm{~Hz}, 4-\mathrm{H}), 7.36(5 \mathrm{H}, \mathrm{m}, 15-17-\mathrm{H}), 5.17$ $(3 \mathrm{H}, \mathrm{m}, 2,13-\mathrm{H}), 4.64(1 \mathrm{H}, \mathrm{dd}, J=2.7 \mathrm{~Hz}, J=9.0 \mathrm{~Hz}, 6-\mathrm{H}), 2.41(2 \mathrm{H}, \mathrm{m}, 8-\mathrm{H}), 2.26\left(1 \mathrm{H}, \mathrm{m}, 7-\mathrm{H}_{\mathrm{a}}\right), 1.94$ $\left(1 \mathrm{H}, \mathrm{m}, 7-\mathrm{H}_{\mathrm{b}}\right), 1.42(3 \mathrm{H}, \mathrm{d}, J=6.9 \mathrm{~Hz}, 3-\mathrm{H}) ;{ }^{13} \mathrm{C}-\mathrm{NMR}\left(75.5 \mathrm{MHz}, \mathrm{DMSO}-\mathrm{d}_{6}\right) \delta_{\mathrm{C}} 174.1(9-\mathrm{C}), 171.0(5-\mathrm{C})$, 158.3 (1-C), 150.9 (12-C), 136.0 (14-C), 128.8 (2C, 16-C), 128.5 (17-C), 128.0 (15-C), 67.5 (13-C), 59.3 (6-C), 40.2 (2-C), $31.3(8-\mathrm{C}), 22.3(7-\mathrm{C}), 19.6(3-\mathrm{C}) ; v_{\max } / \mathrm{cm}^{-1} 3289(\mathrm{~N}-\mathrm{H}), 2993,2868,2739,2615$ (tetrazole), $1780(\mathrm{C}=\mathrm{O}), 1701(\mathrm{C}=\mathrm{O}), 1655(\mathrm{C}=\mathrm{O}), 1545(\mathrm{~N}-\mathrm{H}), 1236(\mathrm{C}-\mathrm{O})$; MS(ESI) $m / z 381.2(\mathrm{M}+\mathrm{Na})^{+} . \mathrm{CHN}$ [Found: $\mathrm{C}, 53.63 ; \mathrm{H}, 5.10 ; \mathrm{N}, 23.18 . \mathrm{C}_{16} \mathrm{H}_{18} \mathrm{~N}_{6} \mathrm{O}_{4}$ requires $\mathrm{C}, 53.63 ; \mathrm{H}, 5.06 ; \mathrm{N}, 23.45 \%$ ].

(S)-N-((S)-1-(1H-tetrazol-5-yl)ethyl)-5-oxopyrrolidine-2-carboxamide (14f-LL): Cbz-L-pyroglutamyl-1-Laminoethyltetrazole (13f-LL, $0.44 \mathrm{~g}, 1.2 \mathrm{mmol}$ ) was reacted by general method E. Following filtration, the solid residue was washed with methanol and the filtrate was evaporated under reduced pressure. The residual oil was triturated with diethyl ether to give the title compound as a white solid $(0.23 \mathrm{~g}$, $84 \%)$. Further purification was performed by Prep HPLC method A. The reaction and the work up were monitored by TLC (ethanol, $\left.\mathrm{R}_{\mathrm{f}}: 0.3\right)$. Mp: $160{ }^{\circ} \mathrm{C}$ (decomposed); ${ }^{1} \mathrm{H}-\mathrm{NMR}\left(300 \mathrm{MHz}, \mathrm{D}_{2} \mathrm{O}\right) \delta_{\mathrm{H}}$ $5.35(1 \mathrm{H}$, quart, $J=7.2 \mathrm{~Hz}, 2-\mathrm{H}), 4.34(1 \mathrm{H}, \mathrm{dd}, J=4.8 \mathrm{~Hz}, J=8.4 \mathrm{~Hz}, 6-\mathrm{H}), 2.52\left(1 \mathrm{H}, \mathrm{m}, 7-\mathrm{H}_{\mathrm{a}}\right), 2.40(2 \mathrm{H}$, $\mathrm{m}, 8-\mathrm{H}) 2.04\left(1 \mathrm{H}, \mathrm{m}, 7-\mathrm{H}_{\mathrm{b}}\right), 1.61(3 \mathrm{H}, \mathrm{d}, J=6.9 \mathrm{~Hz}, 3-\mathrm{H}) ;{ }^{13} \mathrm{C}-\mathrm{NMR}\left(75.5 \mathrm{MHz}, \mathrm{D}_{2} \mathrm{O}\right) \delta_{\mathrm{C}} 182.3(9-\mathrm{C})$, $174.6(5-\mathrm{C}), 159.0(1-\mathrm{C}), 56.9(6-\mathrm{C}), 41.0(2-\mathrm{C}), 29.3(8-\mathrm{C}), 25.0(7-\mathrm{C}), 18.1(3-\mathrm{C}) ; v_{\max } / \mathrm{cm}^{-1} 3262(\mathrm{~N}-\mathrm{H})$, $1649(\mathrm{C}=\mathrm{O}), 1547(\mathrm{~N}-\mathrm{H})$; MS(ESI) $\mathrm{m} / z$ 225.1 $(\mathrm{M}+\mathrm{H})^{+}$. HRMS (Found $(\mathrm{M}+\mathrm{H})^{+}$225.1096. Calcd. for $\mathrm{C}_{8} \mathrm{H}_{13} \mathrm{O}_{2} \mathrm{~N}_{6}$ : $(\mathrm{M}+\mathrm{H})^{+}$225.1095.); (Purity test: HPLC method A).

Benzyl-N-[(1S)-2-phenyl-1-\{[(1S)-1-(1H-1,2,3,4-tetrazol-5-yl)ethyl]carbamoyl\}ethyl]carbamate (13j-LL): Prepared using general method G. The Fmoc group of Fmoc-1-L-aminoethyltetrazole attached to 2-chlorotrityl chloride resin (resin:loading; 1:1 ratio; $1.0 \mathrm{mmol}$ ) was removed, this was monitored by the Fmoc and TNBS tests. After the coupling of Cbz-L-phenylalanine with the resin, the title compound was cleaved off. The cleaving mixture (TFA/DCM/TIS, ratio 5:95:1 eq) was removed by 
evaporation under reduced pressure, and washed with petroleum ether $\left(40-60{ }^{\circ} \mathrm{C}\right)$ to obtain the product as white crystals $(0.32 \mathrm{~g}, 79 \%)$. Further purification was performed using a CombiFlash EZ Prep system (Teledyne-ISCO, Lincoln, NE, USA, eluent: gradient: dichloromethane - methanol $0-30 \%$ ). The reaction and the work up were monitored by TLC (eluent: ethyl acetate, $\left.\mathrm{R}_{\mathrm{f}}: 0.11\right)$. Mp: 191-193 ${ }^{\circ} \mathrm{C} ;{ }^{1} \mathrm{H}-\mathrm{NMR}\left(300 \mathrm{MHz}\right.$, DMSO-d 6 ) $\delta_{\mathrm{H}} 16.21(1 \mathrm{H}, \mathrm{brs}, 8.72(1 \mathrm{H}, \mathrm{d}, J=7.5 \mathrm{~Hz}, 4-\mathrm{H}), 7.44(1 \mathrm{H}, \mathrm{d}$, $J=8.7 \mathrm{~Hz}, 12-\mathrm{H}), 7.33-7.24(10 \mathrm{H}, \mathrm{m}, 9,10,11,17,18,19-\mathrm{H}), 5.27(1 \mathrm{H}$, quint, $6.9 \mathrm{~Hz}, 2-\mathrm{H}), 4.96(1 \mathrm{H}, \mathrm{d}$, $J=13.5 \mathrm{~Hz}, 15 \mathrm{a}-\mathrm{H}), 4.92(1 \mathrm{H}, \mathrm{d}, J=13.5 \mathrm{~Hz}, 15 \mathrm{~b}-\mathrm{H}), 4.30(1 \mathrm{H}, \mathrm{m}, 6-\mathrm{H}), 3.03(1 \mathrm{H}, \mathrm{dd}, J=3.3 \mathrm{~Hz}, J=$ $13.8 \mathrm{~Hz}, 7 \mathrm{a}-\mathrm{H}), 2.72(1 \mathrm{H}, \mathrm{dd}, J=10.8 \mathrm{~Hz}, J=13.5 \mathrm{~Hz}, 7 \mathrm{~b}-\mathrm{H}), 1.52(3 \mathrm{H}, \mathrm{d}, J=6.9 \mathrm{~Hz}, 3-\mathrm{H}) ;{ }^{13} \mathrm{C}-\mathrm{NMR}$ (75.5 MHz, DMSO-d 6 ) $\delta_{\mathrm{C}} 171.7$ (5-C), 158.7 (1-C), 156.3 (14-C), 138.5 (8-C), 137.5 (16-C), 129.6, 128.7, 128.5, 128.1, 127.9, 126.7 (9,10,11,17,18,19-C), 65.7 (15-C), 56.5 (6-C), 40.0 (2-C), 37.8 (7-C), 19.7 (3-C); $v_{\max } / \mathrm{cm}^{-1} 3300(\mathrm{~N}-\mathrm{H}), 2984,2874,2741,2615$ (tetrazole), $1684(\mathrm{C}=\mathrm{O}), 1651(\mathrm{C}=\mathrm{O}), 1531(\mathrm{~N}-\mathrm{H}), 1234$ (C-O); MS(ESI) $m / z$ 417.2 (M + Na) ${ }^{+}$; $\mathrm{CHN}$ [Found: $\mathrm{C}, 60.78 ; \mathrm{H}, 5.68 ; \mathrm{N}, 20.92 . \mathrm{C}_{20} \mathrm{H}_{22} \mathrm{~N}_{6} \mathrm{O}_{3}$ requires $\mathrm{C}$, 60.90; H, 5.62; N, 21.31\%].

(2S)-2-Amino-3-phenyl-N-[(1S)-1-(1H-1,2,3,4-tetrazol-5-yl)ethyl]propanamide (14j-LL): Cbz-L-phenylalanyl1-L-aminoethyltetrazole (13j-LL, $0.30 \mathrm{~g}, 0.8 \mathrm{mmol})$ was deprotected by general method E. Following filtration, the solid residue was washed with ethanol, which was discarded. The residue was washed with water, which was freeze dried, then purified by column chromatography (eluent: dichloromethane - ethanol 10:1, 8:1, 6:1, 1:1 then 0:1 ratio) to give the pure product as a white solid (40 mg, 20\%). Further purification was performed by Prep HPLC method A. The reaction and the work up were monitored by TLC (eluent: ethanol, $\mathrm{R}_{\mathrm{f}}$ : 0.39). Mp: $152-155^{\circ} \mathrm{C} ;{ }^{1} \mathrm{H}-\mathrm{NMR}\left(300 \mathrm{MHz}, \mathrm{D}_{2} \mathrm{O}\right) \delta_{\mathrm{H}} 7.15(3 \mathrm{H}, \mathrm{m}, 10,11-\mathrm{H})$, $7.01(2 \mathrm{H}, \mathrm{m}, 9-\mathrm{H}), 5.24(1 \mathrm{H}$, quart, $J=6.9 \mathrm{~Hz}, 2-\mathrm{H}), 3.77(1 \mathrm{H}, \mathrm{m}, 6-\mathrm{H}), 2.97(1 \mathrm{H}, \mathrm{dd}, J=6.0, J=13.5 \mathrm{~Hz}$, 7a-H), $2.89(1 \mathrm{H}, \mathrm{dd}, J=7.8, J=13.5 \mathrm{~Hz}, 7 \mathrm{~b}-\mathrm{H}), 1.43(3 \mathrm{H}, \mathrm{d}, J=7.2 \mathrm{~Hz}, 3-\mathrm{H}) ;{ }^{13} \mathrm{C}-\mathrm{NMR}\left(75.5 \mathrm{MHz}, \mathrm{D}_{2} \mathrm{O}\right)$ $\delta_{C} 163.5$ (1-C), $150.6(5-C), 135.5$ (8-C), 129.2 (9-C), 128.6 (10-C), 127.1 (11-C), 55.5 (6-C), 41.3 (2-C), 39.3 (7-C), $19.3(3-\mathrm{C}) ; v_{\max } / \mathrm{cm}^{-1} 3217(\mathrm{~N}-\mathrm{H}), 1651(\mathrm{C}=\mathrm{O}), 1528(\mathrm{~N}-\mathrm{H}) ; \mathrm{MS}(\mathrm{ESI}) \mathrm{m} / z 283.2(\mathrm{M}+\mathrm{Na})^{+}$. HRMS (Found $(\mathrm{M}+\mathrm{H})^{+}$261.1462. Calcd. for $\mathrm{C}_{12} \mathrm{H}_{17} \mathrm{ON}_{6}$ : $(\mathrm{M}+\mathrm{H})^{+}$261.1458.); (Purity test: HPLC method A).

Benzyl-N-[(1S)-1-\{[(1S)-1-(1H-1,2,3,4-tetrazol-5-yl)propyl]carbamoyllethyl]carbamate (13b-LL): Prepared using general method G. The Fmoc group of the Fmoc-1-L-aminopropyltetrazole attached to 2-chlorotrityl chloride resin (resin:loading; 1:1 ratio; $2.9 \mathrm{mmol}$ ) was removed. After coupling of Cbz-L-alanine with the resin, the title compound was cleaved off. The cleaving mixture (TFA/DCM/TIS, ratio 5:95:1 eq) was removed by evaporation under reduced pressure. The crude product was subsequently washed with petroleum ether $\left(40-60^{\circ} \mathrm{C}\right)$ to obtain the product as white crystals $(0.49 \mathrm{~g}$, 52\%). Mp: $174-175^{\circ} \mathrm{C} ;{ }^{1} \mathrm{H}-\mathrm{NMR}\left(300 \mathrm{MHz}, \mathrm{DMSO}_{6}\right) \delta_{\mathrm{H}} 8.44(1 \mathrm{H}, \mathrm{d}, J=7.5 \mathrm{~Hz}, 5-\mathrm{H}), 7.41(1 \mathrm{H}, \mathrm{d}, J=$ $7.2 \mathrm{~Hz}, 9-\mathrm{H}), 7.34(5 \mathrm{H}, \mathrm{m}, 14,15,16-\mathrm{H}), 5.06(1 \mathrm{H}, \mathrm{m}, 2-\mathrm{H}), 5.02(2 \mathrm{H}, \mathrm{s}, 12-\mathrm{H}), 4.10(1 \mathrm{H}$, quint, $J=6.9 \mathrm{~Hz}$, 7-H), $1.88(2 \mathrm{H}, \mathrm{m}, 3-\mathrm{H}), 1.19(3 \mathrm{H}, \mathrm{d}, J=7.2 \mathrm{~Hz}, 8-\mathrm{H}), 0.87(3 \mathrm{H}, \mathrm{t}, J=7.2 \mathrm{~Hz}, 4-\mathrm{H}) ;{ }^{13} \mathrm{C}-\mathrm{NMR}(75.5 \mathrm{MHz}$, DMSO-d $\left.{ }_{6}\right) \delta_{C} 173.0(6-C), 156.8(1-C), 156.1(11-C), 137.5(13-C), 128.8$ (15-C), 128.2 (16-C), 128.1 (14-C), 65.8 (12-C), 50.4 (7-C), $45.8(2-\mathrm{C}), 26.8(3-\mathrm{C}), 18.4(8-\mathrm{C}), 10.6(4-\mathrm{C}) ; v_{\max } / \mathrm{cm}^{-1} 3300(\mathrm{~N}-\mathrm{H}), 3265(\mathrm{~N}-\mathrm{H})$, 2976, 2876, 2735, 2617 (tetrazole), $1691(\mathrm{C}=\mathrm{O}), 1651(\mathrm{C}=\mathrm{O}), 1533(\mathrm{~N}-\mathrm{H}), 1246$ (C-O); MS(ESI) m/z 333.1 $(\mathrm{M}+\mathrm{H})^{+} ; \mathrm{CHN}$ [Found: $\mathrm{C}, 54.20 ; \mathrm{H}, 6.11 ; \mathrm{N}, 24.91 . \mathrm{C}_{15} \mathrm{H}_{20} \mathrm{~N}_{6} \mathrm{O}_{3}$ requires $\mathrm{C}, 54.21 ; \mathrm{H}, 6.07 ; \mathrm{N}, 25.29 \%$ ].

(2S)-2-Amino-N-[(1S)-1-(1H-1,2,3,4-tetrazol-5-yl)propyl]propanamide $\quad(\mathbf{1 4 b}-\mathbf{L L})$ : Cbz-L-alanyl-1-Laminopropyltetrazole (13b-LL, $0.40 \mathrm{~g}, 1.2 \mathrm{mmol}$ ) was deprotected by general method E. Following filtration, the solid residue was washed with ethanol, which was discarded. The residue was washed with water, which was freeze dried to give the product as a white solid ( $206 \mathrm{mg}, 86 \%)$. Due to poor solubility, the corresponding hydrochloride salt was prepared using $2 \mathrm{M} \mathrm{HCl}$ in diethyl ether solution $(20 \mathrm{~mL})$ for characterization (hygroscopic solid). Further purification was performed by Prep HPLC method A. The reaction and the work up were monitored by TLC (eluent: ethanol, $\left.\mathrm{R}_{\mathrm{f}}: 0.12\right) .{ }^{1} \mathrm{H}-\mathrm{NMR}$ $\left(300 \mathrm{MHz}, \mathrm{DMSO}-\mathrm{d}_{6}\right) \delta_{\mathrm{H}} 9.17(1 \mathrm{H}, \mathrm{d}, J=7.6 \mathrm{~Hz}, 5-\mathrm{H}), 8.34(3 \mathrm{H}, \mathrm{brs}, 9-\mathrm{H}), 5.09(1 \mathrm{H}$, quart, $J=7.8 \mathrm{~Hz}$, 2-H), $3.93(1 \mathrm{H}$, quart, $J=6.7 \mathrm{~Hz}, 7-\mathrm{H}), 1.92(2 \mathrm{H}, \mathrm{m}, 3-\mathrm{H}), 1.38(3 \mathrm{H}, \mathrm{d}, J=7.0 \mathrm{~Hz}, 8-\mathrm{H}), 0.90(3 \mathrm{H}, \mathrm{t}, J=7.4$ $\mathrm{Hz}, 4-\mathrm{H}) ;{ }^{13} \mathrm{C}-\mathrm{NMR}\left(75.5 \mathrm{MHz}, \mathrm{DMSO}^{-} \mathrm{d}_{6}\right) \delta_{\mathrm{C}} 170.0$ (6-C), 158.0 (1-C), 48.6 (7-C), 46.4 (2-C), 26.8 (3-C), 
17.4 (8-C), 10.6 (4-C); IR; MS(ESI) m/z 199.1 (M + H) ${ }^{+}$; HRMS (Found $(\mathrm{M}+\mathrm{H})^{+}$199.1302. Calcd. for $\mathrm{C}_{7} \mathrm{H}_{15} \mathrm{ON}_{6}:(\mathrm{M}+\mathrm{H})^{+}$199.1302.); (Purity test: HPLC method A).

N-[(1S)-1-\{[(1S)-1-\{[(1S)-1-(1H-1,2,3,4-tetrazol-5-yl)ethyl]carbamoyl\}ethyl]carbamoyl\} ethyl]carbamate (13 -LLL): Prepared using general method G. The Fmoc group of Fmoc-1-L-aminoethyltetrazole attached to the 2-chlorotrityl chloride resin (resin:loading; 1:1 ratio; $1.0 \mathrm{mmol}$ ) was removed, this was monitored by the Fmoc and TNBS tests. After the coupling of Fmoc-L-alanine with the resin, the Fmoc group was removed again. Finally, Cbz-L-alanine was attached to the resin, and the title compound was cleaved off. The cleaving mixture (TFA/DCM/TIS, ratio 5:95:1 eq) was removed by evaporation under reduced pressure, and washed with petroleum ether $\left(40-60^{\circ} \mathrm{C}\right)$ to obtain the product as white crystals $(0.19 \mathrm{~g}$, 47\%). Further purification was performed by Prep HPLC method A. Mp: $199-201^{\circ} \mathrm{C}$ (melted and decomposed); ${ }^{1} \mathrm{H}-\mathrm{NMR}\left(300 \mathrm{MHz}, \mathrm{DMSO}_{\mathrm{d}}\right) \delta_{\mathrm{H}} 16.09(13-\mathrm{H}), 8.48(1 \mathrm{H}, \mathrm{d}, J=6.9 \mathrm{~Hz}, 4-\mathrm{H}), 7.93(1 \mathrm{H}, \mathrm{d}$, $J=7.5 \mathrm{~Hz}, 8-\mathrm{H}), 7.42(1 \mathrm{H}, \mathrm{d}, J=7.2 \mathrm{~Hz}, 12-\mathrm{H}), 7.35(5 \mathrm{H}, \mathrm{m}, 17-19-\mathrm{H}), 5.21(1 \mathrm{H}$, quint, $J=6.9 \mathrm{~Hz}, 2-\mathrm{H})$, $5.02(2 \mathrm{H}, \mathrm{s}, 15-\mathrm{H}), 4.29(1 \mathrm{H}$, quint, $J=7.2 \mathrm{~Hz}, 6-\mathrm{H}), 4.06(1 \mathrm{H}$, quint, $J=7.2 \mathrm{~Hz}, 10-\mathrm{H}), 1.49(3 \mathrm{H}, \mathrm{d}, J=6.9$ $\mathrm{Hz}, 3-\mathrm{H}), 1.19(6 \mathrm{H}, \mathrm{d}, J=6.9 \mathrm{~Hz}, 7,11-\mathrm{H}) ;{ }^{13} \mathrm{C}-\mathrm{NMR}\left(75.5 \mathrm{MHz}, \mathrm{DMSO}-\mathrm{d}_{6}\right) \delta_{\mathrm{C}} 172.6$ (9-C), 172.3 (5-C), 159.1 (1-C), 156.1 (14-C), 137.5 (16-C), 128.8 (18-C), 128.2 (19-C), 128.1 (17-C), 65.8 (15-C), 50.4 (10-C), 48.4 (6-C), 40.9 (2-C), 19.7 (3-C), 18.5 (7-C), 18.4 (11-C); $v_{\max } / \mathrm{cm}^{-1}$ 3298(N-H), $1694(\mathrm{C}=\mathrm{O}), 1643(\mathrm{C}=\mathrm{O})$, $1526(\mathrm{~N}-\mathrm{H}), 1219$ (C-O); MS(ESI) $\mathrm{m} / \mathrm{z} 390.2(\mathrm{M}+\mathrm{H})^{+}$; HRMS (Found $(\mathrm{M}+\mathrm{H})^{+}$390.1883. Calcd. for $\mathrm{C}_{17} \mathrm{H}_{24} \mathrm{O}_{4} \mathrm{~N}_{7}:(\mathrm{M}+\mathrm{H})^{+}$390.1884.); (Purity test: HPLC method C).

(S)-N-((S)-1-(1H-tetrazol-5-yl)ethyl)-2-((S)-2-aminopropanamido)propanamide (14c-LLL): Cbz-L-alanylL-alanyl-1-L-aminoethyltetrazole (13c-LLL, $0.12 \mathrm{~g}, 0.31 \mathrm{mmol}$ ) was reacted by the general method E. Following the filtration, the solid residue was washed with methanol, then the filtrate was evaporated under reduced pressure to give the crude product $(1.11 \mathrm{~g}, 95 \%)$, further recrystallization from a methanol - ethyl acetate mixture provided the pure product as white crystals $(0.477 \mathrm{~g}, 40 \%)$. Further purification was performed by Prep HPLC method A. The reaction and the work up were monitored by TLC (eluent: ethanol, $\left.\mathrm{R}_{\mathrm{f}}: 0.13\right)$. Mp: $135^{\circ} \mathrm{C}$ (melted and decomposed); ${ }^{1} \mathrm{H}-\mathrm{NMR}\left(300 \mathrm{MHz}, \mathrm{D}_{2} \mathrm{O}\right) \delta_{\mathrm{H}}$ $5.25(1 \mathrm{H}$, quart, $J=7.2 \mathrm{~Hz}, 2-\mathrm{H}), 4.30(1 \mathrm{H}$, quart, $J=7.2 \mathrm{~Hz}, 6-\mathrm{H}), 3.95(1 \mathrm{H}$, quart, $J=6.9 \mathrm{~Hz}, 10-\mathrm{H}), 1.52$ $(3 \mathrm{H}, \mathrm{d}, J=7.2 \mathrm{~Hz}, 3-\mathrm{H}), 1.43(3 \mathrm{H}, \mathrm{d}, J=7.2 \mathrm{~Hz}, 11-\mathrm{H}), 1.33(3 \mathrm{H}, \mathrm{d}, J=7.2 \mathrm{~Hz}, 7-\mathrm{H}) ;{ }^{13} \mathrm{C}-\mathrm{NMR}(75.5 \mathrm{MHz}$, $\left.\mathrm{D}_{2} \mathrm{O}\right) \delta_{\mathrm{C}} 173.6(5-\mathrm{C}), 171.7$ (9-C), 164.1 (1-C), 49.8 (6-C), 49.0 (10-C), 42.0 (2-C), 19.4 (3-C), 17.0 (11-C), $16.5(7-\mathrm{C}) ; v_{\max } / \mathrm{cm}^{-1} 3252(\mathrm{~N}-\mathrm{H}), 1639(\mathrm{C}=\mathrm{O}), 1539(\mathrm{~N}-\mathrm{H}) ; \mathrm{MS}(\mathrm{ESI}) \mathrm{m} / z 256.1(\mathrm{M}+\mathrm{H})^{+}$; HRMS (Found $(\mathrm{M}+\mathrm{H})^{+}$256.1520. Calcd. for $\mathrm{C}_{9} \mathrm{H}_{18} \mathrm{O}_{2} \mathrm{~N}_{7}:(\mathrm{M}+\mathrm{H})^{+}$256.1516.); (Purity test: HPLC method A).

3-\{[(1S)-1-\{[(1S)-1-(1H-1,2,3,4-tetrazol-5-yl)ethyl]carbamoyl\}ethyl]carbamoyl\}propanoic acid (16-LL): Prepared using general method G. The Fmoc group of Fmoc-1-L-aminoethyltetrazole attached to the 2-chlorotrityl chloride resin (resin:loading; 1:2 ratio; $1.4 \mathrm{mmol}$ ) was removed. After the coupling of Fmoc-L-alanine with the resin, the Fmoc group was removed again. Finally, a succinyl group was attached to the resin using succinic anhydride, and the title compound was cleaved off. The cleaving mixture (TFA/water/TIS, ratio 95:2.5:2.5) was removed by evaporation under reduced pressure, and recrystallized from a water - acetone solvent mixture to obtain the product as white crystals $(0.16 \mathrm{~g}$, $40 \%$ ). The reaction and the work up were monitored by TLC (eluent: ethyl acetate - ethanol - drop of glacial acetic acid 1:1 ratio, $\left.\mathrm{R}_{\mathrm{f}}: 0.21\right)$. Mp: $170-171^{\circ} \mathrm{C} ;{ }^{1} \mathrm{H}-\mathrm{NMR}\left(300 \mathrm{MHz}, \mathrm{D}_{2} \mathrm{O}\right) \delta_{\mathrm{H}} 5.32(1 \mathrm{H}$, quart, $J=$ $7.2 \mathrm{~Hz}, 2-\mathrm{H}), 4.28(1 \mathrm{H}$, quart, $J=7.2 \mathrm{~Hz}, 6-\mathrm{H}), 2.64(2 \mathrm{H}, \mathrm{m}, 11-\mathrm{H}), 2.54(2 \mathrm{H}, \mathrm{m}, 10-\mathrm{H}), 1.62(3 \mathrm{H}, \mathrm{d}, J=6.9$ $\mathrm{Hz}, 3-\mathrm{H}), 1.35$ (3H, d, J = 7.2 Hz, 7-H); ${ }^{13} \mathrm{C}-\mathrm{NMR}\left(75.5 \mathrm{MHz}, \mathrm{D}_{2} \mathrm{O}\right) \delta_{\mathrm{C}} 176.9$ (12-C), 175.0 (9-C), 174.9 (5-C), 158.5 (1-C), 49.7 (6-C), 40.7 (2-C), 29.9 (10-C), 29.0 (11-C), 17.8 (3-C), $16.4(7-C) ; v_{\max } / \mathrm{cm}^{-1} 3358$ $(\mathrm{N}-\mathrm{H}), 3254(\mathrm{O}-\mathrm{H}), 2992,2945,2886,2778,2712$ (tetrazole), $1713(\mathrm{C}=\mathrm{O}), 1636(\mathrm{C}=\mathrm{O}), 1543(\mathrm{~N}-\mathrm{H}), 1526$ (N-H), 1231 (C-O); MS(MALDI) $m / z 285.30(\mathrm{M}+\mathrm{H})^{+}$; HRMS (Found $(\mathrm{M}+\mathrm{H})^{+}$285.1310. Calcd. for $\mathrm{C}_{10} \mathrm{H}_{17} \mathrm{O}_{4} \mathrm{~N}_{6}$ : $(\mathrm{M}+\mathrm{H})^{+}$285.1306.); (Purity test: HPLC method B).

3-\{[(1S)-1-\{[(1S)-1-\{[(1S)-1-(1H-1,2,3,4-tetrazol-5-yl)ethyl]carbamoyl\}ethyl]carbamoyl\}ethyl]-carbamoyl\}propanoic acid (17-LLL): Prepared using general method G. The Fmoc group of Fmoc-1-L-aminoethyltetrazole attached to the 2-chlorotrityl chloride resin (resin:loading; 1:2 ratio; $2.8 \mathrm{mmol}$ ) was removed. After the 
coupling of Fmoc-L-alanine with the resin, the Fmoc group was removed, and the free amino group was coupled with Fmoc-L-alanine again. After removing the Fmoc protection, a succinyl group was attached to the resin using succinic anhydride, and the title compound was cleaved off. The cleaving mixture (TFA/water/TIS, ratio 95:2.5:2.5) was removed by evaporation under reduced pressure, and triturated with diethyl ether to obtain the product as white crystals $(0.39 \mathrm{~g}, 79 \%)$. Further purification was performed by Prep HPLC method A. The reaction and the work up were monitored by TLC (eluent: ethyl acetate ethanol - drop of glacial acetic acid 1:1 ratio, $\left.\mathrm{R}_{\mathrm{f}}: 0.22\right)$. Mp: $186{ }^{\circ} \mathrm{C}$ (melted and decomposed); ${ }^{1} \mathrm{H}-\mathrm{NMR}$ $\left(300 \mathrm{MHz}, \mathrm{D}_{2} \mathrm{O}\right) \delta_{\mathrm{H}} 5.32(1 \mathrm{H}$, quart, $J=7.2 \mathrm{~Hz}, 2-\mathrm{H}), 4.29(1 \mathrm{H}$, quart, $J=7.2 \mathrm{~Hz}, 6-\mathrm{H}), 4.21(1 \mathrm{H}$, quart, $J=$ $7.2 \mathrm{~Hz}, 10-\mathrm{H}), 2.66(2 \mathrm{H}, \mathrm{m}, 16-\mathrm{H}), 2.55(2 \mathrm{H}, \mathrm{m}, 15-\mathrm{H}), 1.62(3 \mathrm{H}, \mathrm{d}, J=6.9 \mathrm{~Hz}, 3-\mathrm{H}), 1.35(3 \mathrm{H}, \mathrm{d}, J=7.2 \mathrm{~Hz}$, 7-H), $1.34(3 \mathrm{H}, \mathrm{d}, J=7.2 \mathrm{~Hz}, 11-\mathrm{H}) ;{ }^{13} \mathrm{C}-\mathrm{NMR}\left(75.5 \mathrm{MHz}, \mathrm{D}_{2} \mathrm{O}\right) \delta_{\mathrm{C}} 177.0$ (17-C), $175.3(14-\mathrm{C}), 175.2$ (9-C), 174.6 (5-C), 158.1 (1-C), 50.0 (10-C), 49.6 (6-C), 40.7 (2-C), 29.8 (16-C), 29.0 (15-C), 17.8 (3-C), 16.3 (7-C), 16.2 (11-C); $v_{\max } / \mathrm{cm}^{-1} 3343(\mathrm{~N}-\mathrm{H}), 3381(\mathrm{O}-\mathrm{H}), 1707(\mathrm{C}=\mathrm{O}), 1651(\mathrm{C}=\mathrm{O}), 1634(\mathrm{C}=\mathrm{O}), 1539(\mathrm{~N}-\mathrm{H}), 1201(\mathrm{C}-\mathrm{O})$; MS(MALDI) $m / z 356.30(\mathrm{M}+\mathrm{H})^{+}$. HRMS (Found $(\mathrm{M}+\mathrm{H})^{+}$356.1682. Calcd. for $\mathrm{C}_{13} \mathrm{H}_{22} \mathrm{O}_{5} \mathrm{~N}_{7}:(\mathrm{M}+\mathrm{H})^{+}$ 356.1677.) (Purity test: HPLC method A).

3-\{[(1S)-1-\{[(1S)-1-\{[(1S)-1-\{[(1S)-1-(1H-1,2,3,4-tetrazol-5-yl)ethyl]carbamoyl\}ethyl]carbamoyl\}ethyl]-carbamoyl\} ethyl]carbamoyl propanoic acid (18-LLLL): Prepared using general method G. The Fmoc group of Fmoc-1-L-aminoethyltetrazole attached to the 2-chlorotrityl chloride resin (resin:loading; 1:1 ratio; $1.5 \mathrm{mmol}$ ) was removed, and resin was coupled with Fmoc-L-alanine, the Fmoc deprotection and coupling with Fmoc-L-alanine procedure was repeated 2 more times. After removing the Fmoc protection for the final time, a succinyl group was attached to the resin using succinic anhydride, and the title compound was cleaved off. The cleaving mixture (TFA/water/TIS, ratio 95:2.5:2.5) was removed by evaporation under reduced pressure. The residue was triturated with diethyl ether to obtain the product as a white solid $(0.44 \mathrm{~g}, 68 \%)$. Further purification was carried out by column chromatography (eluent: ethyl acetate - ethanol 4:1, 1:1 then 0:1 ratio) and by Prep HPLC method A. The reaction and the work up were monitored by TLC (eluent: ethanol, $\mathrm{R}_{\mathrm{f}}$ : 0.21). Mp: $231{ }^{\circ} \mathrm{C}$ (decomposed); ${ }^{1} \mathrm{H}-\mathrm{NMR}\left(300 \mathrm{MHz}, \mathrm{D}_{2} \mathrm{O}\right)$ $\delta_{\mathrm{H}} 5.32(1 \mathrm{H}$, quart, J = 7.0 Hz, 2-H), $4.26(3 \mathrm{H}, \mathrm{m}, 6,10,14-\mathrm{H}), 2.64(2 \mathrm{H}, \mathrm{m}, 19-\mathrm{H}), 2.58(2 \mathrm{H}, \mathrm{m}, 18-\mathrm{H}), 1.63$ $(3 \mathrm{H}, \mathrm{d}, \mathrm{J}=7.0 \mathrm{~Hz}, 3-\mathrm{H}), 1.36(9 \mathrm{H}, \mathrm{d}, \mathrm{J}=7.2 \mathrm{~Hz}, 7,11,15-\mathrm{H}) ;{ }^{13} \mathrm{C}-\mathrm{NMR}\left(75.5 \mathrm{MHz}, \mathrm{D}_{2} \mathrm{O}\right) \delta_{\mathrm{C}} 177.9(20-\mathrm{C})$, 175.5 (17-C), 175.3, 174.9, 174.4 (5,9,13-C), 158.7 (1-C), 50.1, 49.8, 49.6 (6,10,14-C), 40.9 (2-C), 29.9 (18-H), 29.2 (19-H), 18.0 (3-C), 16.4, 16.3, 16.2 (7, 11, 15-C); $v_{\max } / \mathrm{cm}^{-1} 3265(\mathrm{~N}-\mathrm{H}), 1690(\mathrm{C}=\mathrm{O}), 1653(\mathrm{C}=\mathrm{O}), 1531$ (N-H), 1223 (C-O); MS(ESI) m/z 425.1 (M-H) ${ }^{-}$; HRMS (Found $(\mathrm{M}+\mathrm{H})^{+}$427.2047. Calcd. for $\mathrm{C}_{16} \mathrm{H}_{27} \mathrm{O}_{6} \mathrm{~N}_{8}$ : $(\mathrm{M}+\mathrm{H})^{+}$427.2048.); (Purity test: HPLC method B).

\subsection{Microbiology}

All MICs were determined using an agar dilution method [41]. This necessitated the use of a defined antagonist-free medium (peptone-free), prepared as previously described with the inclusion of $2 \%$ saponin-lysed horse blood, $25 \mu \mathrm{g} / \mathrm{mL}$ NAD and $25 \mu \mathrm{g} / \mathrm{mL}$ haemin [23]. Test compounds were dissolved in sterile deionised water and incorporated into the antagonist-free medium at a final concentration range of 1-128 mg/L. All bacteria were prepared from fresh $(18 \mathrm{~h})$ subcultures on blood agar. Each isolate was suspended in sterile deionised water to a density equivalent to 0.5 McFarland units using a densitometer (approx. $1.5 \times 10^{8} \mathrm{CFU} / \mathrm{mL}$ ) and then diluted 1 in 15 . A $1 \mu \mathrm{L}$ aliquot of each diluted suspension was then delivered onto plates with a multipoint inoculator to give a final inoculum of approximately 10,000 CFU/spot as recommended [41]. Selected compounds of interest were tested without performing the 1 in 15 dilution resulting in a heavier inoculum of 150,000 CF/spot. This allowed us to assess their ability to inhibit large inocula of commensal bacteria that might potentially be present in clinical samples. All plates (including antimicrobial-free controls) were incubated for 22 $\mathrm{h}$ at $37^{\circ} \mathrm{C}$. The minimum inhibitory concentration (MIC) was recorded as the lowest concentration of test compound that resulted in complete inhibition of bacterial growth. 


\section{Conclusions}

This paper introduces novel antibacterial agents specifically inhibiting the growth of certain bacteria. Such compounds can potentially be exploited to increase the selectivity and effectiveness of the detection of clinically important pathogens by chromogenic or fluorogenic culture media.

Antibacterial agents targeting the common bacterial enzyme alanine racemase were developed and investigated. Two 1-aminoalkyltetrazoles were synthesized as potential alanine racemase inhibitors. All molecules were tested against a collection of clinically relevant pathogenic bacteria. As the transportation of a single alanine unit into the cell is not provided by any bacteria, these molecules did not inhibit the growth of any bacteria when deployed as the simple amino acid analogue.

Selected di- and tri- and succinyl oligo-peptide analogues of L-1-aminoethyltetrazole were designed and synthesized by a novel solid phase peptide coupling method to enable the transportation of these molecules into specially targeted bacterial cells. Many of these peptides displayed significant antibacterial activity. Depending upon the attached amino acids, the substrates caused growth inhibition of bacteria with different levels of selectivity. The selective inhibition of enterococci while not affecting the growth of other Gram-positive cocci by L-pyroglutamyl dipeptide 14f-LL is potentially a valuable result. The most significant example is the selective inhibition of $E$. coli and some Enterobacterales by L-alanyl- 14a-LL, L-leucyl- 14h-LL and dialanyl- 14c-LLL substrates. These compounds should be investigated in clinical applications, as they could provide a selective antibacterial ingredient in a Salmonella selective culture medium.

In this report an important limiting factor is that very few results are presented to demonstrate inhibition of E. coli and growth of Salmonella in the presence of these inhibitors, as only two representative strains of each have been tested. However, the successful application of an analogous inhibitor, alafosfalin, in culture media for Salmonella gives us some expectation that these new inhibitors could demonstrate equivalent utility [42]. Further investigations are clearly warranted and these need to include the testing of a large collection of Salmonella isolates as well as large numbers of other species of Enterobacterales, using procedures that have previously been documented for analogous compounds such as alafosfalin [42]. Furthermore, for any new culture medium, multicentre trials with clinical specimens would be required, as previously described [42].

\section{Patents}

\section{R. J. Anderson, M. Gray, L. Kondacs, S. Orenga, J. Perry, WO 2019/058074 A1 2019.}

Supplementary Materials: The following are available online at http:/www.mdpi.com/1420-3049/25/6/1315/s1. ${ }^{1} \mathrm{H}$ NMR, ${ }^{13} \mathrm{C}$ NMR, and 2D NMR spectra, as well as HRMS, HPLC, IR spectra for novel compounds. Additional microbiological details relating to determination of MIC values.

Author Contributions: Conceptualization, M.G., S.O., R.J.A.; investigation, L.A.K., J.D.P., E.C.L.M.; Writing-original draft; L.A.K.; supervision-M.G., R.J.A.; Writing—review and editing M.G., J.D.P., S.O. All authors have read and agreed to the published version of the manuscript.

Funding: This research was funded by bioMerieux Ltd.

Conflicts of Interest: The authors declare no conflict of interest.

\section{References}

1. Perry, J.D. A decade of development of chromogenic culture media for clinical microbiology in an era of molecular diagnostics. Clin. Microbiol. Rev. 2017, 30, 449-479. [CrossRef] [PubMed]

2. Park, C.E.; Rayman, M.K.; Szabo, R.; Stankiewicz, Z.K. Selective enrichment of Shigella in the presence of Escherichia coli by use of 4-chloro-2-cyclopentylphenyl beta-D-galactopyranoside. Can. J. Microbiol. 1976, 22, 654-657. [CrossRef] [PubMed]

3. Conti, P.; Tamborini, L.; Pinto, A.; Blondel, A.; Minoprio, P.; Mozzarelli, A.; Micheli, C.D. Drug discovery targeting amino acid racemases. Chem. Rev. 2011, 111, 6919-6946. [CrossRef] [PubMed] 
4. Azam, M.A.; Jayaram, U. Inhibitors of alanine racemase enzyme: A review. J. Enzyme Inhib. Med. Chem. 2016, 31, 517-526. [CrossRef] [PubMed]

5. Badet, B.; Inagaki, K.; Soda, K.; Walsh, C.T. Time-dependent inhibition of Bacillus stearothermophilus alanine racemase by (l-aminoethyl)phosphonate isomers by isomerization to noncovalent slowly dissociating enzyme-(1-aminoethyl)phosphonate complexes. Biochemistry. 1986, 25, 3275-3282. [CrossRef] [PubMed]

6. Atherton, F.R.; Hall, M.J.; Hassall, C.H.; Holmes, S.W.; Lambert, R.W.; Lloyd, W.J.; Ringrose, P.S. Phosphonopeptide antibacterial agents related to alafosfalin: design, synthesis, and structure-activity relationships. Antimicrob. Agents Chemother. 1980, 18, 897-905. [CrossRef]

7. Atherton, F.R.; Hassall, C.H.; Lambert, R.W. Synthesis and structure-activity relationships of antibacterial phosphonopeptides incorporating (l-aminoethy1)phosphonic acid and (aminomethy1)phosphonic acid. J. Med. Chem. 1986, 29, 29-40. [CrossRef]

8. Atwal, K.S.; Ahmed, S.Z.; Bird, J.E.; Delaney, C.L.; Dickinson, K.E.; Ferrara, F.N.; Hedberg, A.; Miller, A.V.; Moreland, S.; O'Reilly, B.C.; et al. Dihydropyrimidine angiotensin II receptor antagonists. J. Med. Chem. 1992, 35, 4751-4763. [CrossRef]

9. Bavetsias, V.; Marriott, J.H.; Melin, C.; Kimbell, R.; Matusiak, Z.S.; Boyle, F.T.; Jackman, A.L. Design and synthesis of cyclopenta[g]quinazoline-based antifolates as inhibitors of thymidylate synthase and potential antitumor agents. J. Med. Chem. 2000, 43, 1910-1926. [CrossRef]

10. Vo-Quang, Y.; Carniato, D.; Vo-Quang, L.; Lacoste, A.-M.; Neuzil, E.; Goffic, F.L. (1-Amino-2-propenyl) phosphonic acid, an inhibitor of alanine racemase and D-alanine-D-alanine ligase. J. Med. Chem. 1986, 29, 579-581. [CrossRef]

11. Severinsen, R.; Lau, J.F.; Bondensgaard, K.; Hansen, B.S.; Begtrup, M.; Ankersen, M. Parallel solid-phase synthesis of disubstituted (5-biphenyltetrazolyl) hydantoins and thiohydantoins targeting the growth hormone secretagogue receptor. Bioorg. Med. Chem. Lett. 2004, 14, 317-320. [CrossRef] [PubMed]

12. Matthews, D.P.; Green, J.E.; Shuker, A.J. Parallel synthesis of alkyl tetrazole derivatives using solid support chemistry. J. Comb. Chem. 2000, 2, 19-23. [CrossRef] [PubMed]

13. Cousaert, N.; Willand, N.; Gesquiere, J.-C.; Tartar, A.; Deprez, B.; Deprez-Poulain, R. Original loading and Suzuki conditions for the solid-phase synthesis of biphenyltetrazoles. Application to the first solid-phase synthesis of irbesartan. Tetrahedron Lett. 2008, 49, 2743-2747. [CrossRef]

14. Yoo, S.-e.; Seo, J.-s.; Yi, K.-y.; Gong, Y.-d. Solid phase synthesis of biphenyltetrazole derivatives. Tetrahedron Lett. 1997, 38, 1203-1206. [CrossRef]

15. Ishiyama, H.; Yoshizawa, K.; Kobayashi, J. Enantioselective total synthesis of eudistomidins G, H, and I. Tetrahedron 2012, 68, 6186-6192. [CrossRef]

16. Chan, W.C.; White, P.D. Fmoc Solid Phase Peptide Synthesis; Oxford University Press: Oxford, UK, 2000; ISBN 0199637253.

17. Viglio, S.; Luisetti, M.; Zanaboni, G.; Doring, G.; Worlitzsch, D.; Cetta, G.; Iadarola, P. Simultaneous determination of Pseudomonas aeruginosa elastase, human leukocyte elastase and cathepsin $\mathrm{G}$ activities by micellar electrokinetic chromatography. J. Chrom. A 1999, 846, 125-134. [CrossRef]

18. Smissman, E.E.; Terada, A.; El-Antably, S. Synthesis of inhibitors of bacterial cell wall biogenesis. Analogs of D-alanyl-D-alanine. J Med Chem. 1976, 19, 165-167. [CrossRef]

19. Morley, J.S.; Payne, J.W.; Hennessey, T.D. Antibacterial activity and uptake into Escherichia coli of backbone-modified analogues of small peptides. J. Gen. Microb. 1983, 129, 3701-3708. [CrossRef]

20. Gilvarg, C. Peptide transport in bacteria. In Ciba Foundation Symposium 4 - Peptide Transport in Bacteria and Mammalian Gut; Gilvarg, C., Ed.; Associated Scientific Publishers: Amsterdam, The Netherlands, 1972.

21. Komeda, H.; Asano, Y. A DmpA-homologous protein from Pseudomonas sp. is a dipeptidase specific for beta-alanyl dipeptides. FEBS J. 2005, 272, 3075-3084. [CrossRef]

22. Zaytsev, A.V.; Anderson, R.J.; Bedernjak, A.; Groundwater, P.W.; Huang, Y.; Perry, J.D.; Orenga, S.; Roger-Dalbert, C.; James, A. Synthesis and testing of chromogenic phenoxazinone substrates for $\beta$-alanyl aminopeptidase. Org. Biomol. Chem. 2008, 6, 682-692. [CrossRef] [PubMed]

23. Atherton, F.R.; Hall, M.J.; Hassall, C.H.; Lambert, R.W.; Ringrose, P.S. Phosphonopeptides as antibacterial agents: rationale, chemistry, and structure-activity relationships. Antimicrob Agents Chemother 1979, 15, 677-683. [CrossRef] [PubMed] 
24. Cheung, K.S.; Boisvert, W.; Lerner, S.A.; Johnston, M. Chloroalanyl antibiotic peptides: antagonism of their antimicrobial effects by L-alanine and L-alanyl peptides in Gram-negative Bacteria. J. Med. Chem. 1986, 29, 2060-2068. [CrossRef] [PubMed]

25. Kametani, T.; Kigasawa, K.; Hiiragi, M.; Wakisaka, K.; Haga, S.; Sugi, H.; Tanigawa, K.; Suzuki, Y.; Fukawa, K.; Saita, O.; et al. Studies on the synthesis of chemotherpeutics. Part XI. Synthesis and antibacterial activities of phosphonopeptides. Heterocycles 1981, 16, 1205-1242. [CrossRef]

26. Doki, S.; Kato, H.E.; Solcan, N.; Iwaki, M.; Koyama, M.; Hattori, M.; Iwase, N.; Tsukazaki, T.; Sugita, Y.; Kandori, H.; et al. Structural basis for dynamic mechanism of proton-coupled symport by the peptide transporter POT. PNAS 2013, 110, 11343-11348. [CrossRef] [PubMed]

27. Anderson, R.J.; Gray, M.; Kondacs, L.; Orenga, S.; Perry, J. Antibacterial compound and uses of same. WO 2019/058074 A1, 28 March 2019.

28. Mineyama, R.; Saito, K. Partial purification and some properties of pyroglutamyl peptidase from Enterococcus faecalis. Microbios 1998, 94, 47-62.

29. Mundinger, S.; Jakob, U.; Bannwarth, W. Unusual orthogonality in the cleavage process of closely related chelating protecting groups for carboxylic acids by using different metal ions. Chem. Eur. J. 2014, 20, 1258-1262. [CrossRef]

30. Mijovic, M.P.V.; Walker, J. Chemistry of Microccin P. Part II. J. Chem. Soc. 1960, 909-916. [CrossRef]

31. Chen, S.T.; Wu, S.H.; Wang, K.T. A simple method for amide formation from protected amino-acids and peptides. Synthesis-Stuttgart 1989, 1, 37-38. [CrossRef]

32. Yamada, T.; Suegane, K.; Kuwata, S.; Watanabe, H. Studies of unusual amino acids and their peptides. VII. The synthesis and the reaction of iminopeptides. Bull. Chem. Soc. Jpn. 1977, 50, 1088-1093. [CrossRef]

33. Grzonka, Z.; Liberek, B. Tetrazole analogues of amino acids and peptide IV. Tetrahedron 1971, $27,1783-1787$. [CrossRef]

34. Itaya, T.; Shimizu, S.; Nakagawa, S.; Morisue, M. Syntheses of optically active, protected and unprotected vinylglycines. Chem. Pharm. Bull. 1994, 42, 1927-1930. [CrossRef]

35. Jia, Z.J.; Song, Y.; Xu, Q.; Kane, B.; Bauer, S.M.; Pandey, A. Benzamides and nicotinamides as syk modulators. European Patent WO2012061418 (A2), 5 October 2012.

36. Mengelberg, M. Umsetzungen von N-substituierten Amino-iminoäthern. Chem. Ber. 1956, 89, 1185-1193.

37. Das, B.; Damodar, K.; Shashikanth, B.; Srinivas, Y.; Kalavthi, I. A mild and efficient catalytic Strecker reaction of $\mathrm{N}$-alkoxycarbonylamino sulfones with trimethylsilyl cyanide using indium(III) chloride: A facile synthesis of $\alpha$-aminonitriles. Synlett 2008, 20, 3133-3136. [CrossRef]

38. Tsuyoshi, M.; Taisaku, T.; Hiroshi, M.; Seiichi, I.; Yoshiaki, T.; Koji, S.; Tsutomu, Y. Process for producing 1-carbamoyl-3,7-dioxo-1,4-diazepane compounds. European Patent EP2025672 (A1), 18 February 2009.

39. Grzonka, Z.; Liberek, B. Tetrazole analogues of amino acid and peptides. Part 1. Preparation of tetrazole analogues of amino acids from amino acids. Rocz. Chem. 1971, 45, 967-980.

40. Manturewicz, M.; Kosson, P.; Grzonka, Z. Synthesis of Fmoc-alpha-aminoalkylterazoles and tetrazole analogue of Leu-enkephalin. Pol. Chem. J. 2007, 81, 1327-1334.

41. Andrews, J.M. Determination of minimum inhibitory concentrations. J. Antimicrob. Chemother. 2001, 48, 5-16. [CrossRef]

42. Perry, J.D.; Riley, G.; Gould, F.K.; Perez, J.M.; Boissier, E.; Ouedraogo, R.T.; Freydière, A.M. Alafosfalin as a selective agent for isolation of Salmonella from clinical samples. J. Clin. Microbiol. 2002, 40, 3913-3916. [CrossRef]

Sample Availability: Samples of the compounds are not available from the authors. 